\title{
Article \\ Caribbean-Wide, Negative Emissions Solution to Sargassum spp. Low-Cost Collection Device and Sustainable Disposal Method
}

\author{
Luke A. Gray ${ }^{1,2, *}$, Andres G. Bisonó León ${ }^{2} \mathbb{D}$, Folkers E. Rojas ${ }^{1}$, Samuel S. Veroneau ${ }^{3}$ and Alexander H. Slocum ${ }^{1}$ \\ 1 Department of Mechanical Engineering, Massachusetts Institute of Technology, 77 Massachusetts Avenue \\ Building 3 Room 443, Cambridge, MA 02139, USA; folkers.rojas@gmail.com (F.E.R.); slocum@mit.edu (A.H.S.) \\ 2 SOS Carbon S.R.L., Suite 1401, Torre Piantini, Avenida Gustavo Mejia Ricart, Distrito Nacional, \\ Santo Domingo, Dominican Republic; andres@soscarbon.com \\ 3 Department of Chemistry and Chemical Biology, Harvard University, Cambridge, MA 02138, USA; \\ sveroneau@g.harvard.edu \\ * Correspondence: luke@lukegray.com; Tel.: +1-603-686-4271
}

\section{check for} updates

Citation: Gray, L.A.; Bisonó León, A.G.; Rojas, F.E.; Veroneau, S.S.; Slocum, A.H. Caribbean-Wide, Negative Emissions Solution to Sargassum spp. Low-Cost Collection Device and Sustainable Disposal Method. Phycology 2021, 1, 49-75. https://doi.org/10.3390/phycology 1010004

Academic Editors: John James Milledge and Anne Desrochers

Received: 31 May 2021

Accepted: 6 August 2021

Published: 12 August 2021

Publisher's Note: MDPI stays neutral with regard to jurisdictional claims in published maps and institutional affiliations.

Copyright: (c) 2021 by the authors. Licensee MDPI, Basel, Switzerland. This article is an open access article distributed under the terms and conditions of the Creative Commons Attribution (CC BY) license (https:// creativecommons.org/licenses/by/ $4.0 /)$.
Abstract: Sargassum spp. blooms exacerbated by climate change and agricultural runoff are inundating Caribbean beaches, emitting toxic fumes and greenhouse gases through decomposition. This hurts tourism, artisanal fishing, shore-based industry, human health, standards-of-living, coastal ecology, and the global climate. Barriers, collection machinery, and Sargassum valorization have been unable to provide sufficient, sustainable, or widespread relief. This article presents a total Sargassum management system that is effective, low-impact, and economically scalable across the Caribbean. Littoral Collection Modules (LCMs), attached to artisanal fishing boats, collect Sargassum in nets which are brought to a barge. When full, the barge is towed to the deep ocean where Sargassum is pumped to 150-200 m depth, whereafter it continues sinking (Sargassum Ocean Sequestration of Carbon; "SOS Carbon"). Costing and negative emissions calculations for this system show cleanup costs $<\$ 1 / \mathrm{m}^{3}$ and emissions reduction potential up to $1.356 \rightarrow 3.029 \mathrm{tCO} 2 \mathrm{e} / \mathrm{dmt}$ Sargassum. COVID-19 decimated Caribbean tourism, adding to the pressures of indebtedness and natural disasters facing the region. The "SOS Carbon strategy" could help the Caribbean "build back better" by establishing a negative emissions industry that builds resilience against Sargassum and flight shame ("flygskam"). Employing fishermen to operate LCMs achieves socioeconomic goals while increasing Sargassum cleanup and avoiding landfilling achieves sustainable development goals.

Keywords: carbon offset; carbon dioxide reduction; negative emissions technologies; Sargassum; Sargassum management; sustainable development

\section{Introduction}

Caribbean coastal zones have experienced increasing and overwhelming inundations of pelagic Sargassum spp. (hereinafter, "Sargassum"). Prior work has documented the beginnings of the recent, unprecedented Sargassum inundations in the Caribbean in 2011 [1], identified its source in the Northern Equatorial Recirculation Region (NERR) [2-5], and identified samples of this pelagic Sargassum as Sargassum natans, making it likely that this new source originated from the Sargasso Sea [6]. Scientists have dubbed this reoccurring archipelago of Sargassum, stretching all the way from West Africa to the Gulf of Mexico, the "great Atlantic Sargassum belt." It is suggested that nutrient inputs from upwelling off West Africa, hurricanes, and discharge from the Amazon River and the Congo River are responsible for recent blooms [7,8]. The persistence of these causes, and the ever-present seed population of Sargassum in the central Atlantic, suggest that recent Sargassum blooms are likely the new normal [7]. While Sargassum usually blooms once a year, giving rise to a "Sargassum season" lasting from April through August, the 2018 and 2019 seasons extended almost until each year's end [9]. 
Pelagic Sargassum found in the Caribbean comprises Sargassum natans I, Sargassum natans VIII, and Sargassum fluitans. Sargassum natans I and Sargassum natans VIII do not have thorns on their stems whereas Sargassum fluitans does. Sargassum natans I has spines on its bladders whereas Sargassum natans VIII usually does not. Sargassum natans I has narrow, delicate leaves while Sargassum fluitans has broader, denser leaves, and Sargassum natans VIII has noticeably larger leaves compared to both other species. Each of these species has different chemical composition and emissions potential [10].

Sargassum is known to make landfall in overwhelmingly large "mats", which then die, decompose, and emit a nauseating smell like rotten eggs (hydrogen sulfide). This has significantly hurt the tourism industry in the Caribbean, the most tourism-dependent region on the planet where, in 2017 , the industry provided over $15 \%$ of direct gross domestic product (GDP) and $\sim 14 \%$ of direct jobs [11]. In 2019, Mexico and the Dominican Republic received $15.5 \%$ and $16.3 \%$ of GDP from travel and tourism, respectively, and $13.3 \%$ and $17.3 \%$ of total employment, respectively. In the smaller islands, e.g., Antigua and Barbuda, U.S. Virgin Islands, British Virgin Islands, and Aruba, travel and tourism's GDP contributions were as high as $42.7 \%, 55.5 \%, 57.0 \%$ and $73.6 \%$, respectively, and total employment contribution was as high as $90.7 \%, 68.8 \%, 66.4 \%$ and $84.3 \%$, respectively [12].

Sargassum has also directly affected civilian life, as hydrogen sulfide from rotting Sargassum can cause severe pulmonary, neurological, and cardiovascular damage as well as nausea, headaches, respiratory irritation, and imbalance [13]. Contact with decaying Sargassum corrodes boats, breakwaters, and other infrastructure. Thick mats of Sargassum can clog propellers and power plant cooling water intakes, disrupting coastal villages and business activities. Fishing equipment and harvests have also been affected. Eutrophication from Sargassum decomposition suffocates shallow-water animals and area coverage obstructs photosynthesis of benthic plants (e.g., corals and seagrasses) [14]. Decaying Sargassum in coastal waters, on beaches, and in disposal areas/landfills emits large amounts of methane into the earth's atmosphere. Clearing land to create landfills for decaying Sargassum wreaks havoc on land-based ecosystems.

In Quintana Roo, Mexico, it is estimated that tourism declined 30-35\% due to Sargassum $[15,16]$. Investment in new tourism development is being discouraged as well [17]. Moreover, the Caribbean brand, synonymous with its pristine beaches, is decaying along with the Sargassum. Some hotels in Quintana Roo spend $\sim \$ 54,000$ per month to remove Sargassum [18]. In 2015, the vice-president of the University of West Indies (UWI) stated that the Sargassum problem is "the greatest single threat [to the Caribbean]" and estimated $\$ 120$ million and massive manpower would be needed to replicate Mexico's brute force cleanup strategy across the Caribbean [19].

The dominant Sargassum management method across the Caribbean, in civilian and high-value resort areas alike, is manual cleanup-i.e., large numbers of workers using pitchforks, wheelbarrows, and trucks to collect and haul Sargassum to landfill. Select resort areas have started installing nearshore barriers and using excavators and conveyorbased collection machines for removing the Sargassum from beaches and barriers. These methods are unable to keep resort beaches, which have a very high standard for cleanliness, completely clear or provide any relief to civilian coastline.

Barriers vary in quality from improvised, low-cost booms made of foam or PVC floats with net skirts, to expensive engineered oil containment booms made with special materials, coatings, and various added performance features. The former quickly succumb to biofouling or wave-forcing and, while the latter can successfully delay Sargassum from making landfall, they must be removed during storms and only last several years before needing replacement. Regardless of barrier quality, appreciable amounts of Sargassum are still forced by wave action underneath barriers or through barrier gaps and make landfall unless immediately removed from along barriers, which is very difficult to conduct with the slow-moving, high-maintenance, high marginal cost conveyor-based collection boats currently used. 
On the overwhelming majority of Caribbean coastlines, there is no Sargassum management infrastructure, so locals are left to deal with negative effects to health and standardsof-living, often while compromising their own livelihoods to collect and dispose of the Sargassum. Figure 1 illustrates the ineffectiveness of current methods, even in high-value resort areas, and highlights the especially severe effects Sargassum can have on civilian coastlines (e.g., fishing villages).

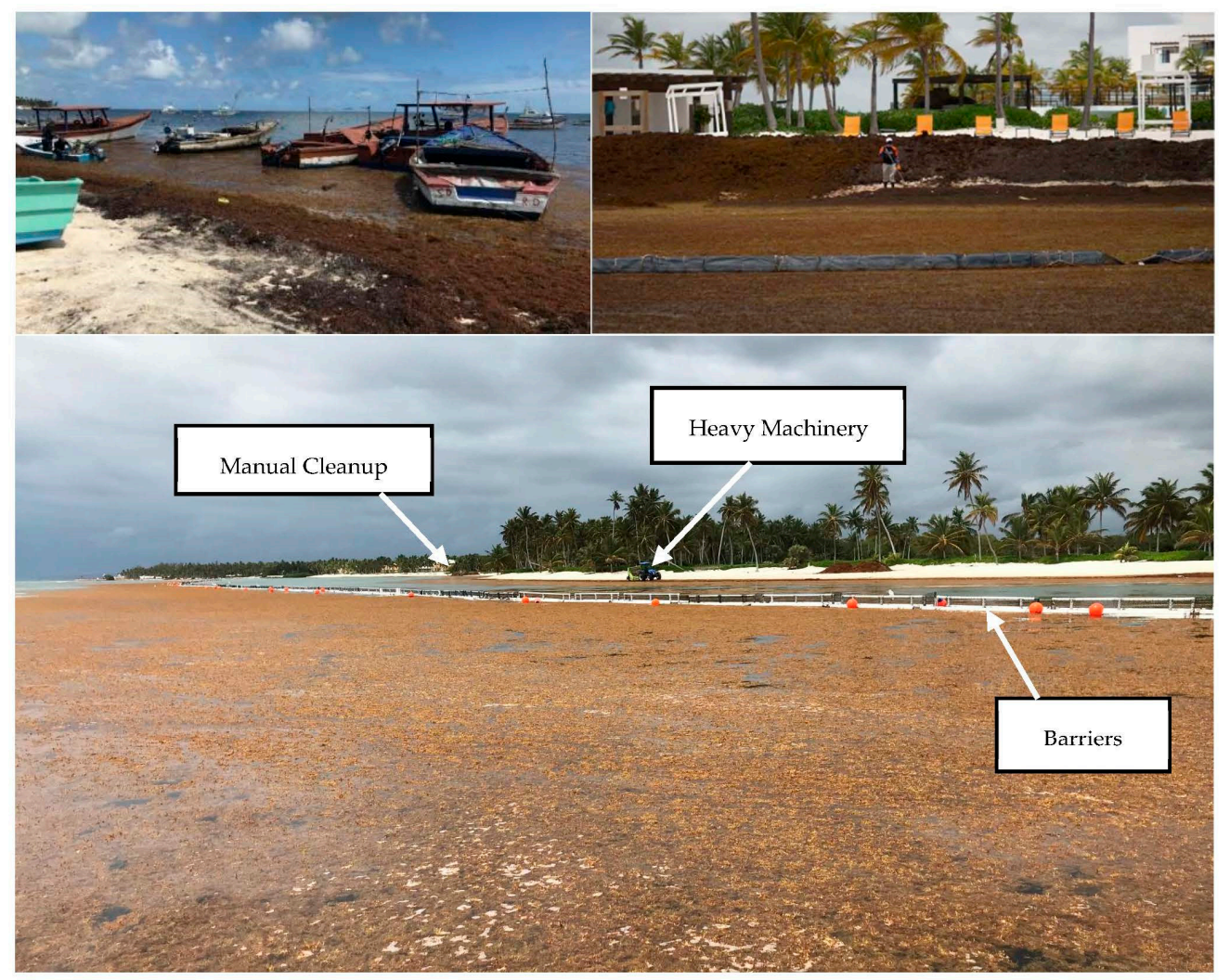

Figure 1. (Top Left) The fishing village located at Cabeza del Toro, between the major tourist locations of Bavaro and Punta Cana, in the Dominican Republic. (Top Right) An unnamed resort in the Caribbean where Sargassum leaks under/through a barrier and is collected manually as it lands on the beach. (Bottom) Sargassum leaks under/through barriers and makes landfall unless constantly removed by conveyor-based collection boats. Once on the beach, Sargassum is removed manually, or with heavy machinery.

There has been academic research and entrepreneurial effort around valorization of Sargassum for many uses-fertilizer/compost, animal feed, biogas, cosmetics, building material, etc. [20]. However, alarming levels of toxic elements in some samples may limit certain uses. Through elemental analysis (viz., inductively coupled plasma mass spectroscopy) arsenic levels as high as 125 ppm were identified in Sargassum samples (see Appendix A for sample preparation). The high values found are corroborated by the high arsenic content of Sargassum shown in previous studies [21]. Furthermore, variable spatial and temporal arrival of Sargassum presents supply chain challenges [20]. Much research, infrastructure, and market development is required before any Sargassum product can meaningfully divert Sargassum from landfill, subsidize cleanup operations, or offset economic losses Caribbean-wide. Meanwhile, relief is urgently needed.

Human activity has contributed greatly to Sargassum inundation of coastlines, but Sargassum could become a symbiotic ocean partner to help mitigate global warming if it can be efficiently collected and valorized or its carbon sequestered [22,23]. Sargassum Ocean Sequestration of Carbon (SOS Carbon) is a strategy based on the principle that if Sargassum pneumatocysts (the grape-like, air-filled bladders that give Sargassum its buoyancy) are 
taken to a critical depth of 150-200 m, hydrostatic pressure at that depth will render the seaweed negatively buoyant to sink and sequester the Sargassum on the deep ocean floor. This critical depth also happens to exceed the mixed layer of the Caribbean so Sargassum pumped to the critical depth will not be transported by currents back to the surface. The phenomena of deep sea Sargassum sequestration sometimes occurs naturally when Sargassum is dragged below the critical depth by Langmuir circulations [24].

The purpose of the work presented herein was to show that simple, robust devices could be used to replicate this natural phenomena on a large scale and to use the gathered process data to build a model that calculates operating costs and negative emissions potential.

\subsection{Design Overview}

Effective Sargassum collection requires versatility in many operating environments (e.g., shorelines, barriers, breakwaters, and marinas), rapid response and mobility, and high collection capacity. This is best achieved with distributed collection by small boat operators, many of whom have lost their livelihoods to the decline of tourism due to Sargassum inundations and COVID-19. The Littoral Collection Module (LCM) is a low-cost, manually operated device designed to attach to practically any small boat found throughout the Caribbean. The LCM has hoops that can be fixed at the waterline on the port and starboard sides of the boat such that long tubular nets can be towed through Sargassum-laden water (Figure 2). Forward motion of LCM boats causes Sargassum to enter and be packed into the nets. When the nets fill, they are cinched closed and left floating in the local collection area. New nets are tied onto the LCM hoops in 30-60 s and skimming resumes. LCM vessels may carry 50+ compacted nets at a time. Detailed design analysis for the key elements of the LCM is provided in Appendix B. It is important to note that even though the LCM is designed to be simple to make and deploy, it must be manufactured with correct materials and methods to ensure mechanical robustness and safety.
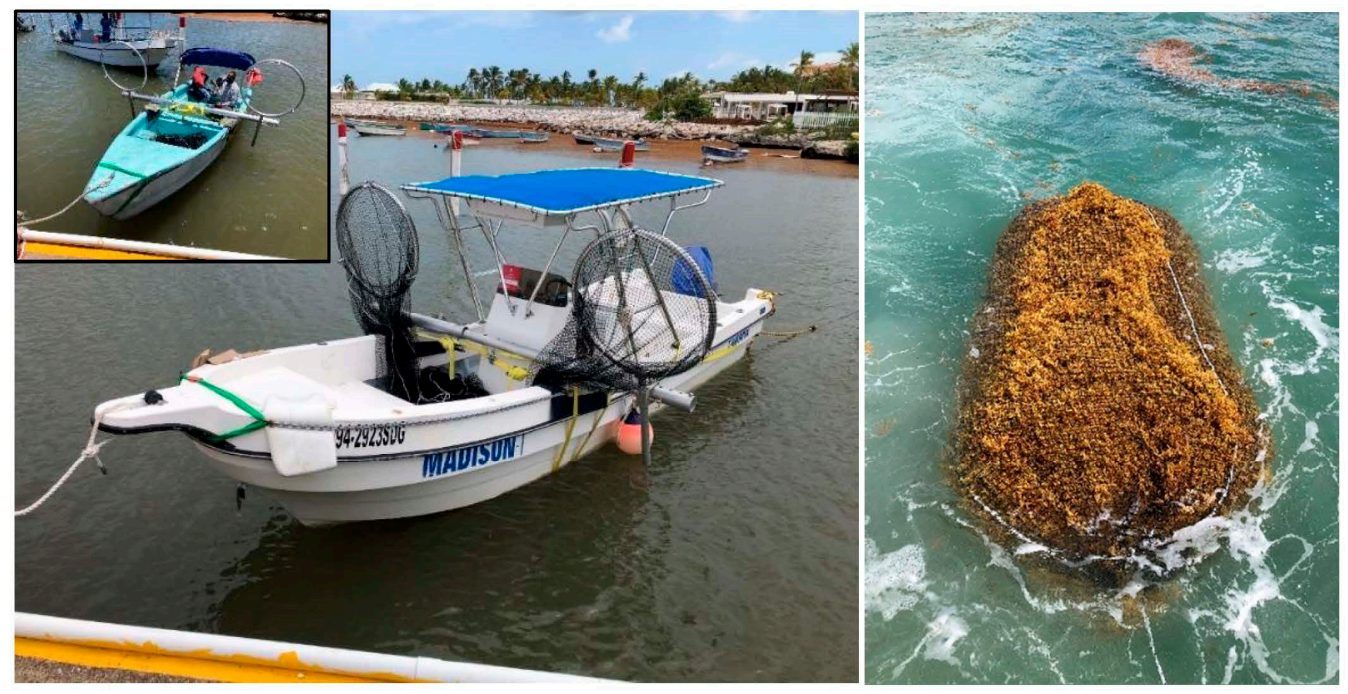

Figure 2. (Top Left) Littoral Collection Module (LCM) fitted onto a traditional "yola" boat. (Left) LCM fitted onto a small powerboat prior to the arms rotating the nets down into the water. (Right) A net of Sargassum filled by the LCM, floating in the water before it is towed away.

Filled nets of Sargassum are attached to a floating towline moored near the local collection area. There are three strategies possible for disposal: (1) if there are options for valorization, the nets of Sargassum can be delivered for processing (filled nets are removed from water individually using small, wear-resistant, plastic sleds towed by ATVs). (2) if local drift models show that the Sargassum will not make landfall again, but rather continue its lifecycle in the open ocean where it eventually sinks through natural senescence, the floating towline can be towed to open water and the nets opened. (3) floating towlines can 
be towed to a centrally located SOS Carbon barge, which is towed to deep water for the Sargassum to be pumped down to the critical depth to sink and sequester it at depths $>1 \mathrm{~km}$.

While the SOS Carbon barge may require more upfront expenditure compared to open ocean towline release, it generates more immediate emissions reductions and is therefore more likely to qualify for carbon credits that subsidize operations. Figure 3 shows the SOS Carbon barge and Figure 4 shows an overview of Sargassum collection, storage, and transportation in Punta Cana. Table 1 summarizes benefits of the LCM and SOS Carbon.

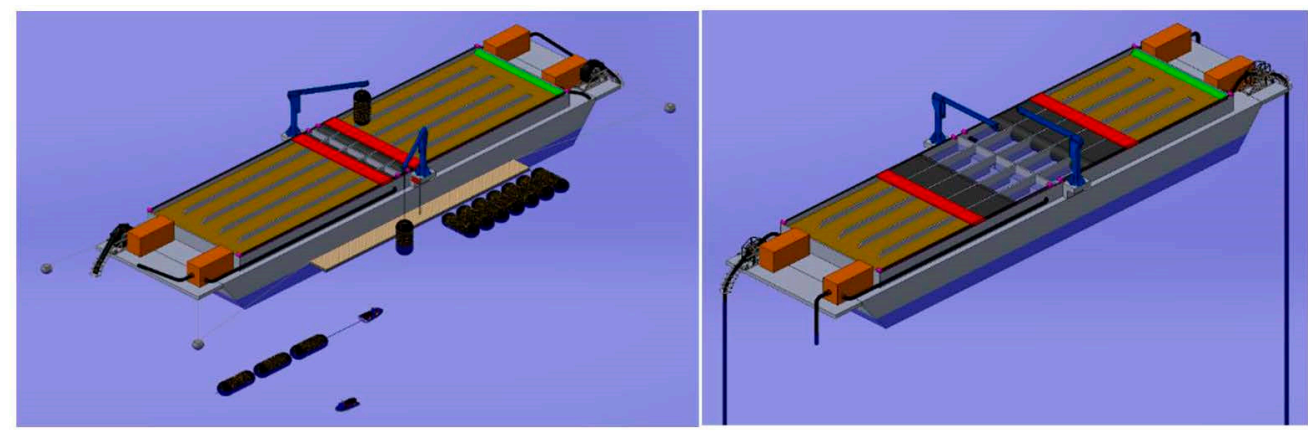

Figure 3. (Left) The Sargassum Ocean Sequestration of Carbon (SOS Carbon) barge being filled, as it is moored near an LCM collection operation. (Right) The SOS Carbon barge in deep water, transporting its Sargassum payload to the critical depth by pumping seawater into the binwall container and pumping the resulting Sargassum-seawater mixture down $\sim 150-200 \mathrm{~m}$ hoses.

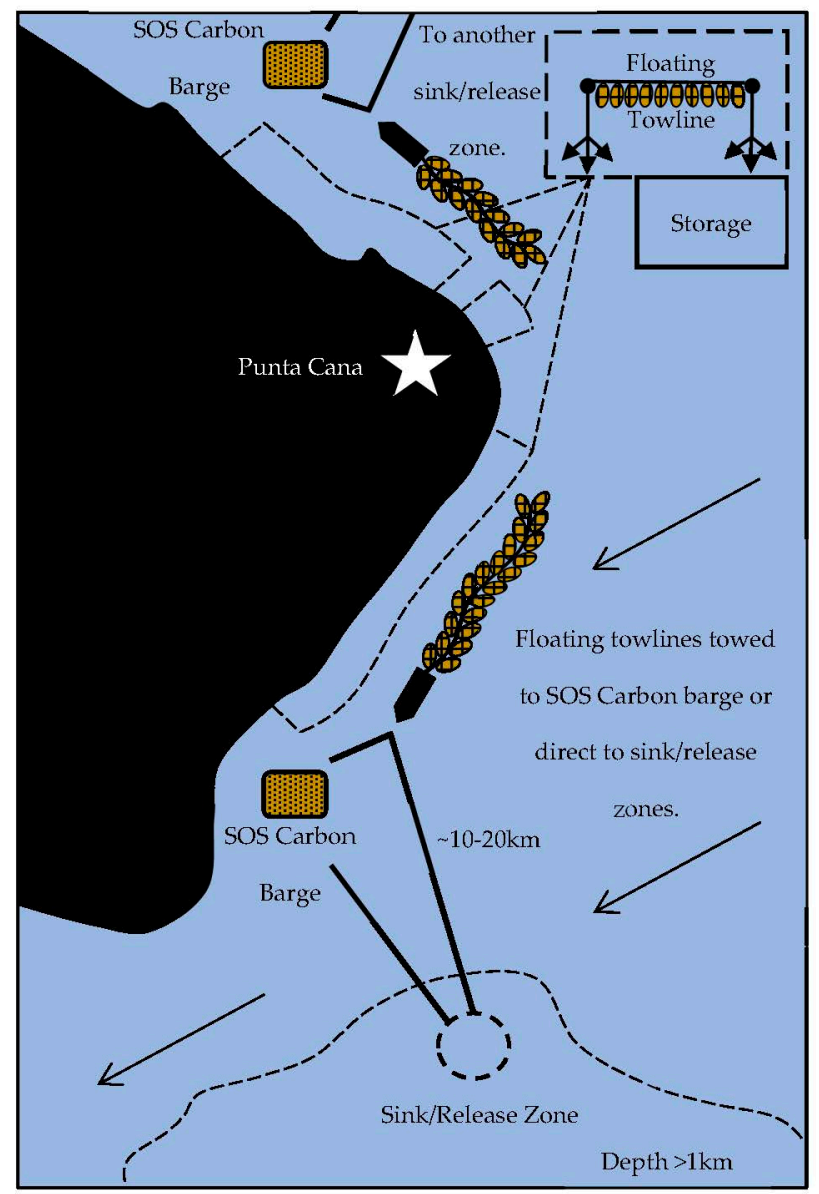

Figure 4. Overview of Sargassum transport and storage in Punta Cana. Nets of Sargassum collected by LCMs are held by floating towlines near the collection area, which are later towed to SOS Carbon barges or offshore for sequestration or release, respectively. In Punta Cana, an appropriate sink/release zone is $\sim 20 \mathrm{~km}$ away, where ocean currents are clear of land and ocean depth $>1 \mathrm{~km}$. 
Table 1. Summary of benefits of the Littoral Collection Module (LCM) and Sargassum Ocean Sequestration of Carbon (SOS Carbon).

LOW CAPITAL_LCMs can be deployed by the tourism industry, national or local governments, and even civilians wanting to protect their local coastline. When not in use, boats can be used for normal functions and there is no capital tied up in expensive, dedicated machinery.

LOW LEAD-TIME-LCM fabrication takes days at most versus months for large conveyor-based harvesters. LCMs can be mass-manufactured and repaired anywhere in the world using only a hand drill, cutting wheel, pipe roller, welder, common extruded aluminum shapes, and off-the-shelf rigging accessories.

LOW MARGINAL-COST-Flattened cost curve enables operation continuously all day, even for small amounts of Sargassum, compared with large conveyor-based harvesters that can only be taken out when significant amounts of Sargassum accumulate, by which time Sargassum will have passed under/through barriers and landed on beaches.

HIGH-CAPACITY-At $300 \mathrm{~m}^{3}$ /LCM/day collection capacity, just 2-3 LCMs match the instantaneous collection rate of large conveyor-based harvesters, and, unlike large conveyor-based harvesters, LCMs can operate all day, due to a low marginal-cost and freedom from daily start-up, maintenance, and washdown procedures. The average Sargassum collection

LCM Collection rate per LCM-operator is up to $10 \times$ the rate of an individual performing onshore, manual raking.

VERSATILE-Mobility of small LCM boats enables fast response time and coverage of large areas. LCMs can collect from barriers, marinas, offshore, and up-river. Shallow draft of LCM boats even enables collecting from the intertidal zone (where Sargassum has already landed) or behind barriers (collecting only Sargassum that leaks through barriers, thereby increasing cost-effectiveness) and may thereby obviate the need for barriers altogether (large conveyor-based harvesters require barriers to keep Sargassum in deeper water).

INCONSPICUOUS-Repurposed LCM boats are already part of the local scenery, compared with large, noisy, special machinery used today.

WORKER-FRIENDLY_LCMs eliminate occupational hazards related to manual shoveling of Sargassum amidst toxic fumes. LCMs are engineered for maximum operator safety (see Appendix B).

LOW-IMPACT-Less risk of damaging critical habitat and infrastructure (e.g., barriers, reefs, and seagrasses) compared to heavy machinery (e.g., trucks, conveyor-based harvesters, and excavators) used currently. LCMs avoid bycatch via up-close visual monitoring. Sargassum nets are transported to access points through water, not over land.

SAND-FREE-Manual collection from beaches yields sand-laden Sargassum, which is hard to process (e.g., compost and anaerobic digestion). LCMs enable collection of Sargassum from water, without any sand. The LCM may therefore be key to the success of Sargassum valorization efforts and many local entrepreneurs starting these small businesses.

HIGH-CAPACITY-Able to dispose of large amounts of Sargassum without limits of market building and supply chains logistics imposed by Sargassum valorization products. MOBILE-Able to easily relocate depending on Sargassum geographic distribution.

SOS Carbon Disposal (and Towline)
INCONSPICUOUS-Sargassum transported and disposed via water rather than carried/trucked through resort areas and dumped in nearby landfills.

NEGATIVE EMISSIONS-Avoiding landfilling and coastal methanogenesis reduces greenhouse gas emissions.

NO PUBLIC HEALTH RISK-No particulate or toxic fumes (hydrogen sulfide) and no risk of toxicity leaching into groundwater. 


\subsection{Pilot Tests}

The SOS Carbon team conducted tests in January 2019 to identify the critical depth whereafter Sargassum becomes negatively buoyant (Figure 5).

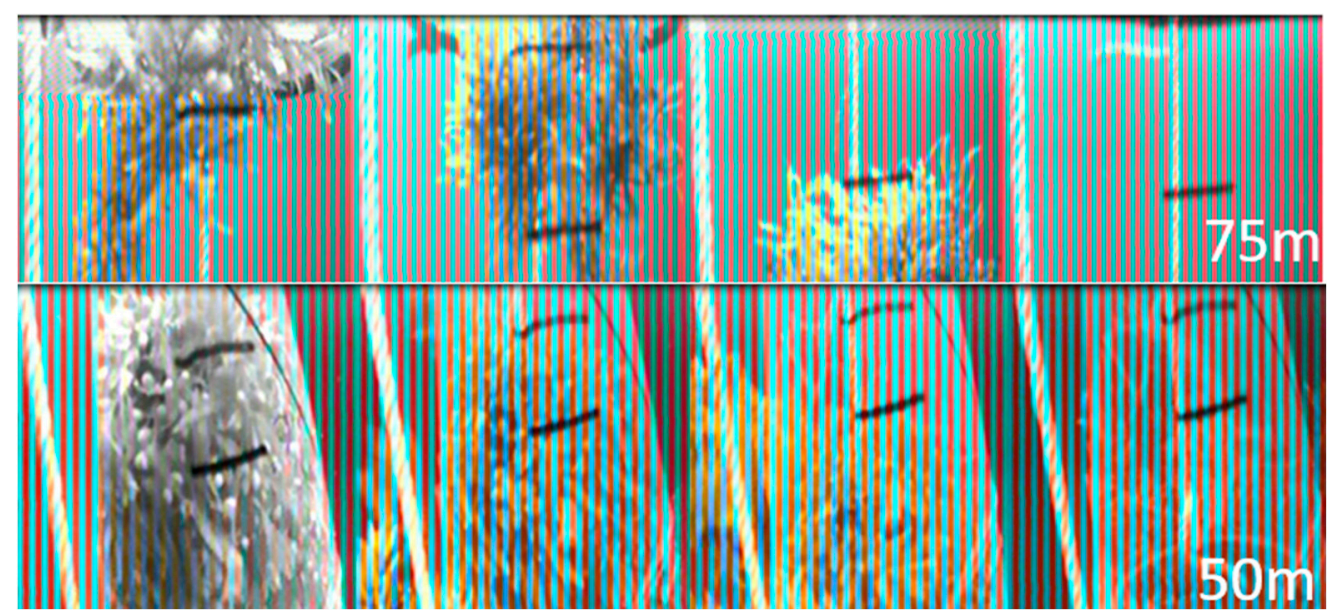

Figure 5. SOS Carbon proof-of-concept tests in Winter 2018-2019. Sargassum was lowered inside a weighted, open-bottom cylinder in seawater until the onset of negative buoyancy. The critical depth varied from 50-150 m, likely due to the variable rate of manual descent and the time-pressure dependence of buoyancy loss. This test showed that previous laboratory results [24] were reproduceable in nature. Sargassum was not observed after sinking.

During Fall 2019, the SOS Carbon team designed, built, and tested a full-scale SOS Carbon pilot system, with the support of 18 sponsors, and installed it onboard an Armada de Republica Dominicana (ARD) vessel, the GC-111 Centaurus. Figure 6 shows the SOS Carbon pilot system design and the finished system during testing.
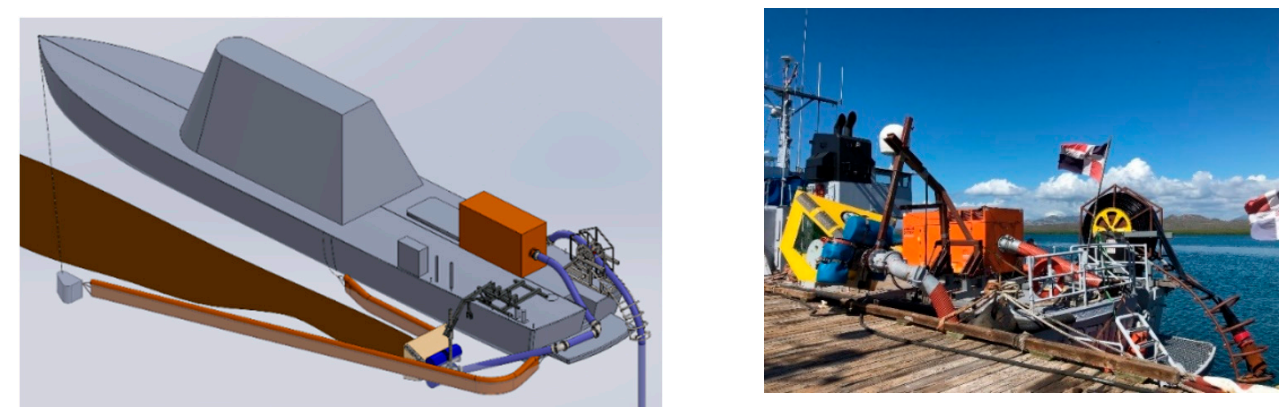

Figure 6. (Left) A design for a 5000 GPM pilot-scale version of the open-ocean, in-situ SOS pumpto-depth vessel that was designed, built, and tested. (Right) The constructed pilot vessel. A future fleet would comprise vessels with up to 50,000 GPM pumping capacity (multiple pumping systems in parallel).

The SOS Carbon pilot system comprises the primary components of a planned SOS Carbon barge while also being designed to intercept mats of Sargassum in the open ocean. While it required a deployment crane, a suction inlet device, and more advanced ship maneuvering compared to just an SOS Carbon barge, it could inform development of a fleet of deep-water SOS Carbon vessels that intercept Sargassum mats far from shore and in situ sequester (more on this in Section 4.2 and Appendix C). Figure 7 shows some results from the SOS Carbon pilot tests. 


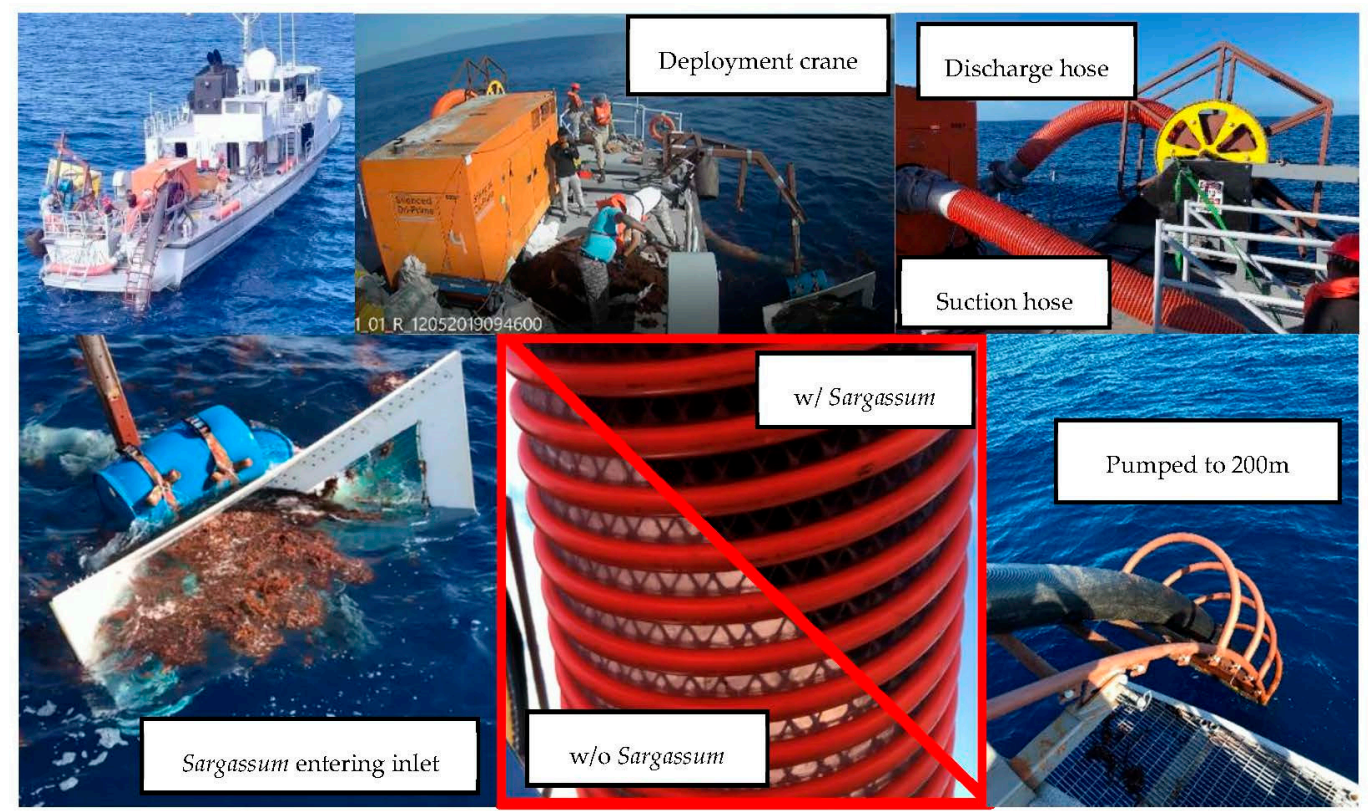

Figure 7. SOS Carbon pilot tests in Fall 2019. (Top Left) Drone view of the SOS Carbon pilot system with the $200 \mathrm{~m}$ lay-flat hose unreeling off the stern of the vessel. (Top Middle) Footage showing the deployment crane lowering the suction inlet device into the water. (Top Right) Transparent suction hose and discharge hose arrangement into and out of the 5000 GPM pump, respectively. (Bottom Left) Sargassum entering the suction inlet device where a co-axial auger meters solids flow. (Bottom Middle) Transparent suction hose shown with and without Sargassum flowing through it. (Bottom Right) The pressurized discharge hose descending from the stern of the vessel, through which Sargassum is transported to the critical depth.

The pump-to-depth system is a mechanically simpler, more energy efficient, and more reliable process for sequestering Sargassum in the ocean compared to, for example, using agriculture-type conveyors and rolling crushers to pulverize Sargassum, which lab tests indicated could not remove air from $100 \%$ of pneumatocysts. Releasing such pulverized Sargassum at the ocean's surface risks it remaining buoyant and being carried by currents to make landfall or decompose before it can sink.

Hydrostatic pressure is $100 \%$ effective at compressing Sargassum pneumatocysts and transporting Sargassum below the mixed layer of the ocean ensures currents will not carry it back to the surface and thus it is most likely to reach the intended deep ocean sequestration location.

Detailed design of the SOS Carbon suction inlet device, deployment crane arm, stern hose reel, and selection of the pump can be found in [25]. Video documentation of LCM tests and SOS Carbon pilot tests can be found on the SOS Carbon, S.R.L. website [26].

\section{Materials and Methods}

\subsection{System Sizing and Costing}

With several days of experience, well maintained boats with $>45 \mathrm{~kW}(\sim 60 \mathrm{hp})$ motors, concentrated Sargassum mats, and no complicated operating conditions (e.g., extremely shallow rocks/reefs or bad weather), a single LCM collection boat could fill 20-30 nets in an hour. This is based on $>500 \mathrm{~h}$ of LCM operation in Punta Cana, in intertidal zones and in front of Sargassum barriers. Collection rates in marinas, along breakwaters, and offshore may differ.

The average amount of Sargassum influx is taken to be $250 \mathrm{~m}^{3} / \mathrm{km} /$ day, based on anecdotal data from three separate locations in Punta Cana, during periods of Sargassum inundation in Fall 2018 and 2019 (detailed accounting is not generally required/available but hotel operations are able to estimate the volume and quantity of trucks used) and from 
actual LCM operations in Punta Cana during Summer 2020 and 2021. System size and average daily kilometric costs are based on this average. In critical areas or in areas with highly variable Sargassum influx, systems may be sized more conservatively.

While LCM boats can operate with 2 persons (a captain and a net handler), maximum efficiencies are achieved with 3 persons (a captain and two net handlers). All personnel wages are conservatively assumed to be $\$ 250 /$ month for the purpose of this study, higher than fair wages currently paid to fishermen in Punta Cana. Wages may vary widely depending on the cost of living in different countries. Health and liability insurance as well as maintenance and repairs on LCM boats, motors, and LCMs themselves is also included at $\$ 300 / \mathrm{LCM} /$ month, assuming 3 persons per LCM. This model does not account for environmental permitting fees, if applicable. Distance to the sink/release zone is assumed to be $15 \mathrm{~km}$. Actual distance can vary between 10 to $20 \mathrm{~km}$, being greater for larger islands (and the mainland) and less for small islands.

All other values assumed in system sizing and costing calculations are summarized in Table 2.

Table 2. Parameters used to calculate system scale and operating costs.

\begin{tabular}{|c|c|c|c|}
\hline Parameter & Value & Symbol & Ref./Explain \\
\hline Avg. kilometric Sargassum influx $\left(\mathrm{m}^{3} / \mathrm{km} /\right.$ day $)$ & 250 & $\dot{V}_{A V G}$ & $500+$ hours operation \\
\hline LCM net diameter $(\mathrm{m})$ & 1 & $d$ & \\
\hline LCM net length (m) & 3 & $l$ & \\
\hline LCM net compaction multiplier & 2 & $M_{\text {net }}$ & \\
\hline Full LCM net roughness (m) & 0.025 & $\varepsilon$ & \\
\hline Length of working day (h/day) & 10 & $T$ & \\
\hline Productive percent of day spent collecting (\%) & $50 \%$ & PP & $500+$ hours operation \\
\hline LCM net collection rate (nets $/ \mathrm{h}$ ) & $20 \rightarrow 30$ & $R$ & $500+$ hours operation \\
\hline Avg. dist. from collection area to towline $(\mathrm{km})$ & 0.125 & $D_{1}$ & 2 towlines per $\mathrm{km}$ \\
\hline Average dist. from towline to barge $(\mathrm{km})$ & 3 & $D_{2}$ & 1 barge per $12 \mathrm{~km}$ \\
\hline Nets LCM can tow at once (nets) & 4 & $Y$ & $500+$ hours operation \\
\hline LCM towing speed (kph) & 3 & $\mathrm{v}_{\text {tow }}$ & $\sim 1.6$ knots \\
\hline LCM transit speed (kph) & 10 & $\mathrm{v}_{\text {transit }}$ & $\sim 5.4$ knots \\
\hline LCM personnel (people/LCM) & 3 & $P_{L C M}$ & 1 capt. +2 net handlers \\
\hline All personnel wage (\$/person/month) & $\$ 250$ & $S$ & $>$ min. wage in DR \\
\hline LCM Ins. + Maint. and Rep. (\$/LCM/month) & $\$ 300$ & $I M R_{L C M}$ & $\mathrm{w} / 3$ people per LCM \\
\hline Cost of diesel fuel (\$/L) & $\$ 0.85$ & $C_{\text {diesel }}$ & Can vary across Caribbean \\
\hline Energy density of diesel fuel (MJ/L) & 38.6 & $E D_{\text {diesel }}$ & {$[27]$} \\
\hline Cost of gasoline $(\$ / L)$ & $\$ 1.25$ & $C_{\text {gasoline }}$ & Can vary across Caribbean \\
\hline LCM fuel consumption $(\mathrm{L} / \mathrm{h})$ & 7.5 & $F C_{L C M}$ & 500+ hours operation \\
\hline Towline tow vessel brake horsepower $(\mathrm{kW})$ & 750 & $B H P_{t v}$ & Assuming small utility boat \\
\hline Length of towline towing vessel (m) & 30 & $L_{t t v}$ & Assuming small utility boat \\
\hline Beam of towline towing vessel $(\mathrm{m})$ & 10 & $B_{t t v}$ & Assuming small utility boat \\
\hline Draught of towline towing vessel (m) & 3 & $H_{t t v}$ & Assuming small utility boat \\
\hline Minimum towline towing velocity $(\mathrm{m} / \mathrm{s})$ & 3 & $\mathrm{v}_{t t v}$ & To empty Sargassum nets \\
\hline Nets attached per meter on towline (nets/m) & 2 & $N$ & Ea. attach. pt. takes 2 nets \\
\hline Towline tow vessel personnel (people/boat) & 4 & $P_{t t v}$ & \\
\hline Tow vessel Ins. + Maint. and Rep. (\$/boat/month) & $\$ 1.5 \mathrm{k}$ & $I M R_{t t v}$ & \\
\hline Binwall barge length $(\mathrm{m})$ & 75 & Large & Listed from marine broker \\
\hline Binwall barge beam (m) & 20 & $B_{\text {barge }}$ & Listed from marine broker \\
\hline Binwall barge draught $(\mathrm{m})$ & 4 & $H_{\text {barge }}$ & Listed from marine broker \\
\hline Barge towing velocity $(\mathrm{m} / \mathrm{s})$ & 4 & $\mathrm{v}_{\text {barge }}$ & $\sim 8$ knots \\
\hline SOS Carbon barge grain capacity $\left(\mathrm{m}^{3}\right)$ & 3000 & $V_{\text {barge }}$ & \\
\hline SOS Carbon barge compaction multiplier & 2 & $M_{\text {barge }}$ & \\
\hline SOS Carbon barge personnel (people/barge) & 5 & Parge & \\
\hline Ins. + Maint. and Rep. (\$/barge/month) & $\$ 10 \mathrm{k}$ & $I M R_{\text {barge }}$ & \\
\hline Wave making resist. as $\%$ of viscous resist. (\%) & $100 \%$ & WMR & USNA [28] \\
\hline Engine efficiency (\%) & $24 \%$ & $\eta_{\text {eng }}$ & e.g., Cummins KTA38 \\
\hline Gear reduction efficiency (\%) & $95 \%$ & $\eta_{\text {gear }}$ & USNA [28] \\
\hline Propulsive efficiency (\%) & $55 \%$ & $\eta_{\text {prop }}$ & USNA [28] \\
\hline Dist. to sink/release zone $(\mathrm{km})$ & 15 & $D_{3}$ & $10-20 \mathrm{~km}$ \\
\hline
\end{tabular}


Table 2. Cont.

\begin{tabular}{cccc}
\hline Parameter & Value & Symbol & Ref./Explain \\
\hline SOS Carbon barge pump capacity $\left(\mathrm{m}^{3} / \mathrm{s}\right)$ & 0.63 & $Q_{\text {pump }}$ & 2 pair 2 ea 5000 GPM pumps \\
SOS Carbon pump solids concentration $(\%)$ & $33 \%$ & $c_{\text {solids }}$ & SOS Carbon pilot [25] \\
Pump fuel consumption $(\mathrm{L} / \mathrm{h})$ & 8 & $F C_{\text {pump }}$ & Godwin DPC300 [29] \\
Loose-pack Sargassum density $\left(\mathrm{kg} / \mathrm{m}^{3}\right)$ & 40 & $\rho_{\text {sarg }}$ & Wet \\
Avg. dry weight as percent of wet weight $(\%)$ & $13.27 \%$ & $K_{A V G}$ & Species average from [10] \\
Density seawater @ STP and st. salinity $\left(\mathrm{kg} / \mathrm{m}^{3}\right)$ & 1023 & $\rho_{\text {sw }}$ & \\
Kinematic viscosity seawater @ $15^{\circ} \mathrm{C}\left(\mathrm{m}^{2} / \mathrm{s}\right)$ & $1.188 \mathrm{e}-6$ & $v_{\text {sw }}$ & Conservative \\
Barge cost $(\$)$ & $\$ 1 \mathrm{MM}$ & $\$_{\text {barge }}$ & Conservative \\
Towline cost $(\$)$ & $\$ 3 \mathrm{k})$ & $\$_{\text {towline }}$ & Godwin DPC300 [29] \\
Pump cost $(\$)$ & $\$ 150 \mathrm{k}$ & $\$_{\text {pump }}$ & Prototypes w/U.S. labor \\
Cost of LCM $(\$ / \mathrm{LCM})$ & $\$ 2000$ & $\$_{L C M}$ & Prototypes w/U.S. labor \\
Cost of nets $(\$ / \mathrm{net})$ & $\$ 30$ & $\$_{\text {net }}$ &
\end{tabular}

The number of LCMs required per kilometer of coast is calculated via Equation (1):

$$
N_{L C M s}=\frac{L \times \dot{V}_{A V G}}{T \times P P \times\left(\frac{\pi \times d^{2} \times l}{4} \times M_{n e t}\right) \times\left(\frac{Y}{\frac{Y}{R}+\left(\frac{D_{1}}{v_{\text {tow }}}+\frac{D_{1}}{v_{\text {transit }}}\right)}\right)} \mid \begin{gathered}
L=1 \mathrm{~km} \\
R=20[\text { nets } / \mathrm{h}]
\end{gathered} \quad \approx 1 \text { LCMs] }
$$

The average number of nets used per kilometer per day can be calculated from Equation (2):

$$
N_{\text {nets }}=\left.\frac{L \times \dot{V}_{A V G}}{\left(\frac{\pi \times d^{2} \times l}{4} \times M_{n e t}\right)}\right|_{L=1 \mathrm{~km}} \approx 60[\text { nets } / \text { day }]
$$

Towline operations will require nets to remain with towlines until they are emptied, Therefore, the number of nets needed per kilometer to sustain continuous operation depends on towline length and towline towing velocity.

Towlines laden with filled nets of Sargassum can be emptied in two ways: (1) once the sink/release zone is reached, all nets are opened and the entire towline is towed until all Sargassum has emptied, or (2) the entire towline is pulled onto the towline towing vessel by a coiling pad or wheel engine and each filled net of Sargassum is detached, hoisted, and gravity discharged into the water with the empty nets then folded and returned for reuse. The former method requires no onboard equipment but requires that the towline towing vessel be capable of towing the towline at a minimum velocity $\mathrm{v}_{t t v}$ in order for nets to empty. The latter method has no minimum velocity requirement, but requires an onboard crane and wheel engine. The former method is assumed in this model.

Towline towing vessels are ideally locally sourced, repurposed vessels. Towline length would therefore often be limited by the towing vessel on hand. Assuming the minimum available towline towing vessel capabilities in Table 2 , the maximum towline length $L_{\text {towline }}$ must satisfy Equation (3):

$$
B H P_{t t v}>\frac{\frac{1}{2} \times \rho_{s w} \times\left(C_{f} \times(4 \times d) \times L_{\text {towline }}+C_{T} \times\left(2 \times H_{t t v}+B_{t t v}\right) \times L_{t t v}\right) \times v_{t t v}^{3}}{\eta_{\text {gear }} \times \eta_{\text {prop }} \times 1000\left[\frac{\mathrm{W}}{\mathrm{kW}}\right]} \quad[\mathrm{kW}]
$$

where

$$
C_{f}=\left(1.89-1.62 \times \log _{10}\left(\frac{\varepsilon}{l}\right)\right)^{-2.5}
$$


is the skin friction factor for a filled net, assuming a fully rough flat plate turbulent boundary layer [30] and

$$
C_{T}=(1+W M R) \times\left(\left(1+19 \times\left(\frac{B_{t t v}}{L_{t t v}}\right)^{2}\right) \times \frac{0.075}{\left(\log _{10}\left(\frac{\mathrm{v}_{t t v} \times L_{t t v}}{v_{s w}}\right)-2\right)^{2}}\right)
$$

is the coefficient of total hull resistance (viscous + wave-making) on the towing vessel [28].

$L_{\text {towline }} \approx 150 \mathrm{~m}$ is therefore the maximum expected towline length (a factor of safety of $\sim 2$ is included), unless a more capable vessel is available for towline towing. The minimum towline towing velocity, $\mathrm{v}_{t t v}=3 \mathrm{~m} / \mathrm{s}(\sim 6$ knots) will enable the towline towing vessel to perform $T P D_{t t v}=T /\left(2 \times 1000[\mathrm{~m} / \mathrm{km}] \times D_{3} / \mathrm{v}_{t t v} / 3600[\mathrm{~s} / \mathrm{h}]\right) \approx 3$ trips to the sink $/$ release zone per day or $T P D_{t t v}^{*}=T /\left(2 \times 1000[\mathrm{~m} / \mathrm{km}] \times D_{2} / \mathrm{v}_{t t v} / 3600[\mathrm{~s} / \mathrm{h}]\right) \approx$ 18 trips to the nearest SOS Carbon barge per day. Towlines could be towed slower than $\mathrm{v}_{t t v}$ to save fuel, but $B H P_{t t v}$ must be provided at $\mathrm{v}_{t t v}$ in order for nets to be emptied. Note that Equation (3) ignores air resistance, viscous pressure drag, and wave making resistance for the towline because of its low freeboard, high length-to-width ratio, and low speedto-length ratio, respectively. Current resistance is also ignored as towing against currents should be avoided. Added wave resistance, steering resistance, and shallow water effects are also ignored because operation should not proceed in high sea states, maneuvering will be minimal, and there will be no operation in shallow water, respectively.

A towline with $L_{\text {towline }}=150 \mathrm{~m}$, with $N=2$ [nets $\left./ \mathrm{m}\right]$ attached, can hold a total of $L_{\text {towline }} \times N=300$ nets and must be emptied every $T T F_{\text {towline }}=L_{\text {towline }} \times N \times$ $\left(\pi \times d^{2} \times l / 4\right) \times M_{\text {net }} /\left(\dot{V}_{A V G} \times L=1 \mathrm{~km}\right) \approx 6$ days. Therefore, a single towline towing vessel could service TPD ttv $\times T T F_{\text {towline }} \approx 17 \mathrm{~km}$ of continuous coastline in the LCM + Towline system during average Sargassum influx. Up to $\left(T T F_{\text {towline }}+1\right) \times N_{\text {nets }}=420$ nets per kilometer could be provided such that collection can continue on days when towlines are being emptied. One redundant towline could be on-hand such that collection can continue on days when primary towlines are being emptied. Therefore, 2 maximum length towlines per kilometer of collection area is assumed. It is assumed that each maximum towline length $L_{\text {towline }}$ is divided into two sections across the collection area such that $D_{1}=0.125 \mathrm{~km}$ to reduce transit times for LCM boats towing filled nets (sections are reconnected for towline transport).

For deep ocean sequestration, the SOS Carbon barge must be towed by a proper ocean-class tug, or self-propelled via outboard motors mounted on the SOS Carbon barge as sized by Equation (4):

$B H P_{\text {barge }}=\frac{\frac{1}{2} \times \rho_{\text {sw }} \times(1+W M R)\left(\left(1+19 \times\left(\frac{B_{\text {barge }}}{L_{\text {barge }}}\right)^{2}\right) \times \frac{0.075}{\left(\log _{10}\left(\frac{v_{\text {barge }} \times L_{\text {barge }}}{v_{\text {sww }}}\right)-2\right)^{2}}\right) \times\left(2 \times H_{\text {barge }}+B_{\text {barge }}\right) \times L_{\text {barge }} \times \mathrm{v}_{\text {barge }}^{3}}{\eta_{\text {gear }} \times \eta_{\text {prop }} \times 1000\left[\frac{\mathrm{W}}{\mathrm{kW}}\right]} \approx 1132[\mathrm{~kW}]$

Note that Equation (4) also ignores air resistance, current resistance, added wave resistance, steering resistance, and shallow water effects. With $\mathrm{v}_{\text {barge }}=4 \mathrm{~m} / \mathrm{s}(\sim 8$ knots $)$, it takes $\left(2 \times 1000[\mathrm{~m} / \mathrm{km}] \times D_{3} / \mathrm{v}_{\text {barge }} / 3600[\mathrm{~s} / \mathrm{h}]\right) \approx 2 \mathrm{~h}$ for each roundtrip to $/$ from the sink/release zone. It is estimated to take $V_{\text {barge }} \times M_{\text {barge }} /\left(Q_{\text {pump }} \times c_{\text {solids }}\right) / 3600[\mathrm{~s} / \mathrm{h}] \approx$ $8 \mathrm{~h}$ to discharge all Sargassum in the SOS Carbon barge. Servicing $4 \times D_{2}=12 \mathrm{~km}$ of coast, it will take TTF $F_{\text {barge }}=V_{\text {barge }} \times M_{\text {barge }} /\left(4 \times D_{2} \times \dot{V}_{A V G}\right) \approx 2$ days for the SOS Carbon barge to fill. 
Wind resistance could increase SOS Carbon barge resistance by as much as $25-30 \%$ [28]. Voyage plans should maintain $50 \%$ of fuel reserve during towing operations. The size of onboard fuel tanks, fuel consumption, and distance to sink/release zones must thus be carefully considered on a regional basis.

The tonnage cost for LCM operation is the same, regardless of whether towlines or SOS Carbon barges are used for disposal. The tonnage cost for LCM collection and transportation to towlines is calculated via Equation (5):

$$
C_{L C M}=F C_{L C M}^{*} \times C_{\text {gasoline }}+\frac{N_{L C M} \times\left(S \times P_{L C M}+I M R_{L C M}\right)}{30\left[\frac{\text { day }}{\text { month }}\right] \times \dot{V}_{A V G} \times \frac{\rho_{\text {sarg }}}{1000\left[\frac{\mathrm{kg}}{\text { tonne }}\right]} \times K_{A V G}} \quad[\$ / \mathrm{dmt}]
$$

where

$$
F C_{L C M}^{*}=\frac{F C_{L C M}}{\left(\frac{Y}{\frac{Y}{\left(R=30\left[\frac{\text { nets }}{\text { hr }}\right]\right)}+\left(\frac{D_{1}}{v_{\text {tow }}}+\frac{D_{1}}{v_{\text {transit }}}\right)}\right) \times\left(\frac{\pi \times d^{2} \times l}{4} \times M_{\text {net }}\right) \times \frac{\rho_{\text {sarg }}}{1000\left[\frac{\mathrm{kg}}{\text { tonne }}\right]} \times K_{A V G}}
$$

The tonnage cost to tow a towline to/from the sink/release zone is calculated via Equation (6):

$$
C_{\text {towline }}=F C_{\text {towline }}^{*} \times C_{\text {diesel }}+\frac{S \times P_{t t v}+I M R_{t t v}}{30\left[\frac{\text { day }}{\text { month }}\right] \times \dot{V}_{A V G} \times(L=17 \mathrm{~km}) \times \frac{\rho_{\text {sarg }}}{1000\left[\frac{\mathrm{kg}}{\text { tonne }}\right]} \times K_{A V G}}[\$ / \mathrm{dmt}]
$$

where

$$
F C_{\text {towline }}^{*}=\frac{2 \times 1000\left[\frac{\mathrm{m}}{\mathrm{km}}\right]}{\eta_{\text {eng }} \times 1000\left[\frac{\mathrm{kW}}{\mathrm{MW}}\right] \times E D_{\text {diesel }} \times \frac{\rho_{\text {sarg }}}{1000\left[\frac{\mathrm{kg}}{\text { tonne }}\right]} \times K_{A V G}} \times\left(\frac{\frac{B H P_{\text {tto }} \times D_{3}}{\mathrm{v}_{\text {ttt }}}}{L_{\text {towline }} \times N \times\left(\frac{\pi \times d^{2} \times l}{4} \times M_{\text {net }}\right)}\right)
$$

The tonnage cost to tow towlines to an SOS Carbon barge and then tow a full SOS Carbon barge to the sink/release zone is calculated via Equation (7):

$$
C_{\text {barge }}=F C_{\text {barge }}^{*} \times C_{\text {diesel }}+\frac{S \times P_{\text {barge }}+I M R_{\text {barge }}+S \times P_{t t v}+I M R_{t t v}}{30\left[\frac{\text { day }}{\text { month }}\right] \times \dot{V}_{A V G} \times(L=12 \mathrm{~km}) \times \frac{\rho_{\text {sarr }}}{1000\left[\frac{\mathrm{kg}}{\text { tonne }}\right]} \times K_{A V G}} \quad[\$ / \mathrm{dmt}]
$$

where

$$
\begin{aligned}
F C_{\text {barge }}^{*}=\frac{2 \times 1000\left[\frac{\mathrm{m}}{\mathrm{km}}\right]}{\eta_{\text {eng }} \times 1000\left[\frac{\mathrm{kW}}{\mathrm{MW}}\right] \times E D_{\text {diesel }} \times \frac{\rho_{\text {sarg }}}{1000\left[\frac{\mathrm{kg}}{\mathrm{tonne}}\right]} \times K_{A V G}} \\
\quad \times\left(\frac{\frac{B H P_{\text {barge }} \times D_{3}}{\mathrm{v}_{\text {barge }}}}{\left(V_{\text {barge }} \times M_{\text {barge }}\right)}+\frac{\frac{B H P_{\text {ttv }} \times D_{2}}{\mathrm{v}_{\text {ttv }}}}{L_{\text {towline }} \times N \times\left(\frac{\pi \times d^{2} \times l}{4} \times M_{\text {net }}\right)}\right)[\mathrm{L} / \mathrm{dmt}]
\end{aligned}
$$

Equation (7) includes the cost of towing towlines to the SOS Carbon barge, which is not the same as the cost of towing towlines all the way to the sink/release zone from Equation (6).

The system curve for pumping Sargassum to depth can be calculated assuming waterequivalence, ignoring relative density, viscosity, and solids-friction effects. This is because flow is vertical, settling velocity is exceeded, and volumetric solids concentration is limited to $c_{\text {solids }}<\sim 33 \%$ by feed augers at the suction hose inlets to prevent clogs and shocks to the pump. For a 200-m long, 12" diameter, lay-flat, polyurethane hose, pressure head at 5000 GPM was calculated to be $\sim 100 \mathrm{kPa}(\sim 15 \mathrm{psi})$. An equivalent fluid model is less appropriate for this scenario (because the Sargassum-seawater mixture is heterogeneous 
and particle sizes are large), but produces a more conservative result of $\sim 120 \mathrm{kPa}(\sim 17 \mathrm{psi})$ as it accounts for relative density and viscosity effects. Typically for horizontal flow and low fluid velocities, heterogeneous solids would be considered settling and this would prohibit the water-equivalence assumption, thereby producing a system curve steeper than an equivalent fluid model under the same conditions. At solids concentration greater than the loose packed concentration of Sargassum (above which solids are pushed against hose walls), a sliding bed or plug flow model may be better suited for calculating the system curve. All of the above models are presented in [25] and can be made available upon request. Based on pump curves and its reputation for transportability, ruggedness, and solids-handling capability, a Godwin DPC300 pump was chosen for SOS Carbon pilot tests and its fuel consumption, which was confirmed in practice, is listed in Table 2 [29]. With this specification, the tonnage cost of pumping-to-depth can be calculated via Equation (8):

$$
C_{\text {pump }}=F C_{\text {pump }}^{*} \times C_{\text {diesel }} \quad[\$ / \mathrm{dmt}]
$$

where

$$
F C_{\text {pump }}^{*}=\frac{4 \times F C_{\text {pump }}}{Q_{\text {pump }} \times c_{\text {solids }} \times 3600\left[\frac{\mathrm{s}}{\mathrm{h}}\right] \times \frac{\rho_{\text {sarg }}}{1000\left[\frac{\mathrm{kg}}{\text { tonne }}\right]} \times K_{A V G}} \quad[\mathrm{~L} / \mathrm{dmt}]
$$

Note that Equation (8) assumes suction pumps and pump-to-depth pumps on the SOS Carbon barge operate at the same pressure head and fuel consumption. This is a conservative simplifying assumption.

Total tonnage costs for the LCM + Towline system and the LCM + Towline + SOS Carbon Barge system are calculated via Equations (9a) and (9b), respectively:

$$
\mathrm{LCM}+\text { Towline : } \quad C_{\text {total }}^{a}=C_{L C M}+C_{\text {towline }} \quad[\$ / \mathrm{dmt}]
$$

$$
\mathrm{LCM}+\text { Towline + SOS Carbon Barge : } \quad C_{\text {total }}^{b}=C_{\mathrm{LCM}}+C_{\text {barge }}+C_{\text {pump }} \quad[\$ / \mathrm{dmt}]
$$

Average daily kilometric costs of cleanup operations for the LCM + Towline system and the LCM + Towline + SOS Carbon Barge system are calculated via Equations (10a) and (10b):

$$
\begin{gathered}
\mathrm{LCM}+\text { Towline : } \quad A D K C^{a}=\frac{C_{\text {total }}^{a} \times K_{A V G} \times \rho_{\text {sarg }}}{1000\left[\frac{\mathrm{kg}}{\text { tonne }}\right]} \times \dot{V}_{A V G} \quad[\$ / \mathrm{km} / \text { day }] \\
\mathrm{LCM}+\text { Towline + SOS Carbon Barge : } \quad A D K C^{b}=\frac{C_{\text {total }}^{b} \times K_{A V G} \times \rho_{\text {sarg }}}{1000\left[\frac{\mathrm{kg}}{\text { tonne }}\right]} \times \dot{V}_{A V G} \quad[\$ / \mathrm{km} / \text { day }]
\end{gathered}
$$

\subsection{Carbon Accounting}

Sargassum, like other macroalgae and microalgae, plays a natural role in oceanic carbon sequestration, and the Sargasso Sea, alone, accounts for $\sim 7 \%$ of the global net biological carbon pump [31]. Natural senescence and sinking of Sargassum biomass [32], the release of recalcitrant dissolved organic carbon [33], and fecal pellets from animals grazing on Sargassum [34], are all ways in which Sargassum helps sequester carbon in the ocean [35].

The central Atlantic Sargassum seed population that feeds Caribbean inundations is therefore likely an important carbon sink. However, when Sargassum makes landfall and decomposes in anaerobic coastal water or landfill, Sargassum's natural carbon pumping contribution is replaced by $\mathrm{CO}_{2}$ and $\mathrm{CH}_{4}$ emissions in addition to the collateral impact Sargassum landings have on coastal carbon sinks such as mangrove forests, seagrass meadows, and coral reefs. 
SOS Carbon can realize emissions reductions by increasing cleanup activity and avoiding landfilling of Sargassum. This model accounts for the global warming potential $\left(\mathrm{GWP}_{100}\right)$ of emissions from Sargassum deposited in landfill and process-fuel emissions from LCM boats, towline towing vessels, SOS Carbon barges, and pumps.

The IPCC (2006) estimates methane landfill emissions from solid waste via Equation (11) [36]:

$$
L_{o}=W \times D O C \times D O C_{f} \times M C F \times F \times \frac{16}{12}\left[\mathrm{~kg} \mathrm{CH}_{4}\right]
$$

where $L_{o}$ is the total methane generation potential ( $\left.\mathrm{kg} \mathrm{CH} 4\right)$ of Sargassum, $W$ is the dry mass of deposited landfill waste $(\mathrm{kg}), D O C$ is the degradable organic carbon fraction of the dry mass of deposited waste, $D O C_{f}$ is the decomposable fraction of $D O C, M C F$ is the methane correction factor, $F$ is the methane fraction of the evolved landfill gas, and $16 / 12$ is the molecular weight ratio $\mathrm{CH}_{4} / \mathrm{C}$. Sargassum values, taken from biogas methane potential tests conducted by J. J. Milledge (2020) [10], are summarized in Table 3.

Table 3. Values for Sargassum natans (S. natans) and Sargassum fluitans (S. fluitans) used to calculate landfill gas emissions. "\%VS" refers to percent volatile solids.

\begin{tabular}{|c|c|c|c|}
\hline Parameter & Value & Symbol & Ref./Explain. \\
\hline S. natans I dry weight percent of wet weight & $12.60 \%$ & $K_{S 1}$ & J. J. Milledge 2020 [10] \\
\hline S. natans VIII dry weight percent of wet weight & $13.50 \%$ & $K_{S 8}$ & J. J. Milledge 2020 [10] \\
\hline S. fluitans dry weight percent of wet weight & $13.70 \%$ & $K_{F}$ & J. J. Milledge 2020 [10] \\
\hline S. natans I \%VS of wet weight & $8.10 \%$ & & J. J. Milledge 2020 [10] \\
\hline S. natans I degradable organic carbon & $64.3 \%$ & $D_{S 1}$ & $\% \mathrm{VS}$ of dry wt. \\
\hline S. natans I decomposable fraction of DOC & $17 \%$ & $D^{\prime} C_{f, S 1}$ & Biodegradability [10] \\
\hline S. natans VIII \%VS of wet weight & $8.91 \%$ & & J. J. Milledge 2020 [10] \\
\hline S. natans VIII degradable organic carbon & $66.0 \%$ & $D_{O C} 8$ & $\% \mathrm{VS}$ of dry wt. \\
\hline S. natans VIII decomposable fraction of DOC & $37 \%$ & $\mathrm{DOC}_{f, S 8}$ & Biodegradability [10] \\
\hline S. fluitans \%VS of wet weight & $9.08 \%$ & & J. J. Milledge 2020 [10] \\
\hline S. fluitans degradable organic carbon & $66.3 \%$ & $D O C_{F}$ & $\% \mathrm{VS}$ of dry wt. \\
\hline S. fluitans decomposable fraction of DOC & $29 \%$ & $D O C_{f, F}$ & Biodegradability [10] \\
\hline Methane correction factor & 0.6 & $M C F$ & $\operatorname{IPCC}(2006)[36]$ \\
\hline Methane vol. fraction of generated landfill gas & 0.5 & $F$ & IPCC (2006) [36] \\
\hline $\mathrm{GWP}_{100}$ of $\mathrm{CH}_{4}\left[\mathrm{kgCO}_{2} \mathrm{e} \mathrm{g}^{-1} \mathrm{CH}_{4}\right]$ & 28 & $\mathrm{GWP}_{\mathrm{CH}_{4}}$ & [37] \\
\hline S. natans I theoretical pot. $\left[\mathrm{mL} \mathrm{CH}_{4} \mathrm{~g}^{-1} \mathrm{VS}\right]$ & 392 & $T M P_{S 1}$ & J. J. Milledge 2020 [10] \\
\hline S. natans VIII theoretical pot. $\left[\mathrm{mL} \mathrm{CH}_{4} \mathrm{~g}^{-1} \mathrm{VS}\right]$ & 395 & $T M P_{S 8}$ & J. J. Milledge 2020 [10] \\
\hline S. fluitans theoretical pot. $\left[\mathrm{mL} \mathrm{CH}_{4} \mathrm{~g}^{-1} \mathrm{VS}\right]$ & 392 & $T M P_{F}$ & J. J. Milledge 2020 [10] \\
\hline S. natans I measured pot. [mL CH $\left.\mathrm{g}^{-1} \mathrm{VS}\right]$ & 65.8 & $M M P_{S 1}$ & J. J. Milledge 2020 [10] \\
\hline S. natans VIII measured pot. [ $\left.\mathrm{mL} \mathrm{CH}_{4} \mathrm{~g}^{-1} \mathrm{VS}\right]$ & 145.1 & $M M P_{S 8}$ & J. J. Milledge 2020 [10] \\
\hline S. fluitans measured pot. [mL CH $\left.\mathrm{CH}^{-1} \mathrm{VS}\right]$ & 112.7 & $M M P_{F}$ & J. J. Milledge 2020 [10] \\
\hline Methane density @ STP $\left(\mathrm{kg} / \mathrm{m}^{3}\right)$ & 0.657 & $\rho_{\mathrm{CH}_{4}}$ & \\
\hline Carbon dioxide density at STP $\left(\mathrm{kg} / \mathrm{m}^{3}\right)$ & 1.98 & $\rho_{\mathrm{CO}_{2}}$ & \\
\hline
\end{tabular}

This model assumes no landfill cover (no methane oxidation), no leaching of DOC, no landfill gas recovery, and no $\mathrm{CO}_{2}$ seepage. The non-methane volumetric fraction of landfill gas is assumed to be $\mathrm{CO}_{2}$ and total $\mathrm{CO}_{2}$ equivalent emissions are calculated from Equation (12):

$$
E_{o}^{a}=\frac{1000\left[\frac{\mathrm{kg}}{\mathrm{dmt}}\right] \times L_{o}}{W} \times\left(G W P_{\mathrm{CH}_{4}}+\frac{(1-F) \times \rho_{\mathrm{CO}_{2}}}{F \times \rho_{\mathrm{CH}_{4}}}\right) \quad\left[\mathrm{kgCO}_{2} \mathrm{e} / \mathrm{dmt}\right]
$$


An alternative method uses the theoretical methane potential and/or measured biogas biochemical methane potential as summarized in Table 3 and calculates total landfill emissions via Equations (13) and (14):

$$
\begin{array}{ccc}
\text { Theoretical : } E_{o}^{b}=T M P_{\text {Sarg }} \times \rho_{\mathrm{CH}_{4}} \times D O C \times\left(G W P_{\mathrm{CH}_{4}}+\frac{(1-F) \times \rho_{\mathrm{CO}_{2}}}{F \times \rho_{\mathrm{CH}_{4}}}\right) & {\left[\mathrm{kgCO}_{2} \mathrm{e} / \mathrm{dmt}\right]} \\
\text { Measured : } E_{o}^{c}=M M P_{\text {Sarg }} \times \rho_{\mathrm{CH}_{4}} \times D O C \times\left(G W P_{\mathrm{CH}_{4}}+\frac{(1-F) \times \rho_{\mathrm{CO}_{2}}}{F \times \rho_{\mathrm{CH}_{4}}}\right) & {\left[\mathrm{kgCO}_{2} \mathrm{e} / \mathrm{dmt}\right]}
\end{array}
$$

Note that J. J. Milledge (2020) [10] reports Sargassum methane potentials significantly lower than theoretical methane potentials, indicating low biodegradability, and suggests this may be due to indigestible fiber and inhibitors. However, biogas methane potential test methods are not standardized, especially for new substrates such as Sargassum, and these laboratory tests do not mimic landfill conditions or timescales. Also note that Equations (12)-(14) refer to symbols from Table 3.

\section{Process Emissions}

Process emissions comprise gasoline typically burned by the LCM boats and diesel fuel burned by larger towline towing vessels, SOS Carbon barges, and pumps, with energy densities of $34.2 \mathrm{MJ} / \mathrm{L}$ and $38.6 \mathrm{MJ} / \mathrm{L}$, respectively [27]. $\mathrm{CH}_{4}$ and $\mathrm{N}_{2} \mathrm{O}$ are ignored in process emissions. Mobile GHG emissions are assumed to be the same as stationary GHG emissions.

The Environmental Protection Agency (EPA) recommends calculating emissions from fuel combustion using Equation (15) [38]:

$$
E=V_{\text {fuel }} \times F C C_{X} \quad\left[\mathrm{kgCO}_{2} / \mathrm{dmt}\right]
$$

where $E$ is the emissions per dry metric tonne of Sargassum processed $\left(\mathrm{kgCO}_{2} / \mathrm{dmt}\right), V_{\text {fuel }}$ is the volume of fuel combusted per dry metric tonne of Sargassum processed (L/dmt), and FCC is the fuel carbon content $\left(\mathrm{kgCO}_{2} / \mathrm{L}\right)$. This calculation must be carried out separately for LCM collection, towline towing, SOS Carbon barge propulsion, and pumping-to-depth. Gasoline and diesel FCCs are $2.348 \mathrm{kgCO}_{2} / \mathrm{L}\left(8.887 \mathrm{kgCO}_{2} /\right.$ gal $)$ and $2.689 \mathrm{kgCO}_{2} / \mathrm{L}$ (10.180 $\left.\mathrm{kgCO}_{2} / \mathrm{gal}\right)$, respectively [39].

LCM collection emissions are calculated using Equation (16):

$$
E_{L C M}=F C_{L C M}^{*} \times F C C_{g a s} \quad\left[\mathrm{kgCO}_{2} / \mathrm{dmt}\right]
$$

Towline transport emissions are calculated using Equation (17):

$$
E_{\text {towline }}=F C_{\text {towline }}^{*} \times F C C_{\text {diesel }} \quad\left[\mathrm{kgCO}_{2} / \mathrm{dmt}\right]
$$

The process emissions to tow towlines to an SOS Carbon barge and then tow a full SOS Carbon barge to the sink/release zone are calculated via Equation (18):

$$
E_{\text {barge }}=\mathrm{FC}_{\text {barge }}^{*} \times F C C_{\text {diesel }} \quad\left[\mathrm{kgCO}_{2} / \mathrm{dmt}\right]
$$

SOS Carbon pump-to-depth emissions are calculated via Equation (19):

$$
E_{\text {pump }}=\mathrm{FC}_{\text {pump }}^{*} \times \mathrm{FCC}_{\text {diesel }} \quad\left[\mathrm{kgCO}_{2} / \mathrm{dmt}\right]
$$

Total process emissions for the LCM + Towline system and the LCM + Towline + SOS Carbon Barge system are calculated via Equations (20a) and (20b), respectively:

$$
\mathrm{LCM}+\text { Towline : } \quad E_{\text {tot }}^{a}=E_{\mathrm{LCM}}+E_{\text {towline }} \quad\left[\mathrm{kgCO}_{2} / \mathrm{dmt}\right]
$$

$$
\mathrm{LCM}+\text { Towline + SOS Carbon Barge : } \quad E_{\text {tot }}^{b}=E_{L C M}+E_{\text {barge }}+E_{\text {pump }} \quad\left[\mathrm{kgCO}_{2} / \mathrm{dmt}\right]
$$




\section{Results}

\subsection{System Sizing and Costing}

Stepwise costs and total costs, for both the LCM + Towline system and the LCM + Towline + SOS Carbon Barge system, are summarized in Table 4. A spreadsheet with these calculations can be found in the Supplementary Material.

Table 4. Summary of costs, including estimated average daily kilometric costs, for the LCM + Towline system and the LCM

+ Towline + SOS Carbon Barge system, respectively.

\begin{tabular}{ccc}
\hline & LCM + Towline & LCM + Towline + Barge \\
\hline Collection + Storage $(\$ / \mathrm{dmt})$ & $\$ 43.94$ & $\$ 43.94$ \\
Transportation to Sink/Release Zone $(\$ / \mathrm{dmt})$ & $\$ 55.22$ & $\$ 63.55$ \\
Pump-to-depth $(\$ / \mathrm{dmt})$ & $\mathrm{n} / \mathrm{a}$ & $\$ 6.84$ \\
Total Tonnage Cost $(\$ / \mathrm{dmt})$ & $\$ 99.16$ & $\$ 114.33$ \\
Total Volumetric Cost $\left(\$ / \mathrm{m}^{3}\right)$ & $\$ 0.53$ & $\$ 0.61$ \\
Average daily kilometric cost $(\$ / \mathrm{km} /$ day $)$ & $\$ 131.59 *$ & $\$ 151.71 *$ \\
\hline
\end{tabular}

* Based on average expected amount of Sargassum of $250 \mathrm{~m}^{3} / \mathrm{km} /$ day-actual amounts of Sargassum received can be highly variable.

Affected countries in the Caribbean, excluding the U.S., Colombia, and Venezuela, but including Guyana, Suriname, and French Guiana, possess a cumulative Caribbean coastline $>20,000 \mathrm{~km}$ and almost half is comprised of small island developing states (SIDS). With the assumption that just $10 \%$ of this total coastline is inhabited and/or serviceable in the near-term, that would indicate a potential for $\sim 6000 \mathrm{LCM}$ personnel direct jobs to be created at a capital cost of $\sim \$ 40 \mathrm{MM}$ for LCMs, towlines, and nets (LCM + Towline system $\mathrm{w} /$ maximum number of nets) and an additional $\sim 250 \mathrm{MM}$ for SOS Carbon barges (LCM + Towline + SOS Carbon Barge system). This translates to $\sim \$ 10 \mathrm{k}$ and $\sim \$ 50 \mathrm{k}$ investments per direct job created for the LCM + Towline and LCM + Towline + SOS Carbon Barge systems, respectively, compared to $>\$ 20 \mathrm{k}$ per direct job for similar highimpact sustainable development projects [40]. These amounts do not include shipping, sales tax, import taxes, LCM boats, upgrading outboard motors on LCM boats (motors should be at least $60 \mathrm{hp}$ to operate in Sargassum), or towline towing vessels, all of which could hopefully be avoided via local manufacturing, tax exemption, and repurposing existing boats. Local manufacturing may also bring about substantial cost savings on LCM, towline, and net fabrication (assumed prices are based on prototypes made by U.S. fabricators). SOS Carbon barges can be made from used ocean-class binwall barges. Additional investments may be required on a local level to create the administrative jobs to manage collection operations.

Total job creation potential across the Caribbean is difficult to estimate without detailed local investigations. Sargassum amounts received, navigability and continuity of coastline, population density, and ecological sensitivity are just a few factors that can determine the necessity and scale of cleanup. Given the size of the Sargassum problem and LCM collection rates, it seems a significant portion of existing artisanal boat fleets could be employed.

\subsection{Carbon Accounting}

Table 5 summarizes the results of Equations (11)-(14). A spreadsheet with these calculations can be found in the Supplementary Material. 
Table 5. Summary of landfill emissions potentials of Sargassum.

\begin{tabular}{cccc}
\hline \multicolumn{4}{c}{ Landfill Emissions Potential $\mathbf{( \mathbf { k g C O } _ { \mathbf { 2 } } \mathbf { e } / \mathbf { d m t } )}$} \\
\hline & S. natans I & S. natans VIII & S. fluitans \\
$E_{o}^{a}$ & 1356 & 3029 & 2384 \\
$E_{o}^{b}$ & 5135 & 5312 & 5294 \\
$E_{o}^{c}$ & 862 & 1951 & 1522 \\
\hline
\end{tabular}

The range of species values for $E_{o}^{a}$ from Equations (11) and (12) were carried forward.

\subsubsection{Process Emissions}

Process emissions results are summarized in Table 6.

Table 6. Summary of process emissions for the LCM + Towline system and the LCM + Towline + SOS Carbon Barge system, respectively.

\begin{tabular}{ccc}
\hline & LCM + Towline & LCM + Towline + Barge \\
\hline Collection + Storage $\left(\mathrm{kgCO}_{2} / \mathrm{dmt}\right)$ & 33 & 33 \\
Transportation to Sink/Release Zone $\left(\mathrm{kgCO}_{2} / \mathrm{dmt}\right)$ & 163 & 110 \\
Pump-to-depth $\left(\mathrm{kgCO}_{2} / \mathrm{dmt}\right)$ & $\mathrm{n} / \mathrm{a}$ & 22 \\
Total process emissions $\left(\mathrm{kgCO}_{2} / \mathrm{dmt}\right)$ & 196 & 165 \\
\hline
\end{tabular}

\subsubsection{Negative Emissions Potential}

The ratio of $\mathrm{CO}_{2}$-equivalent emissions reduced to $\mathrm{CO}_{2}$-equivalent emissions produced for the LCM + Towline + SOS Carbon Barge system is therefore from about 8 to 18, which is very good. Although it cannot be assumed that all Sargassum disposed of using the LCM + Towline system never makes landfall again, a significant fraction of emissions reductions could still be achieved, although satellite identification and drift models must be improved to enable verification. Assuming the LCM + Towline + SOS Carbon Barge system is implemented across $10 \%$ of the $20,000 \mathrm{~km}$ of coast in the Caribbean receiving an average of $250 \mathrm{~m}^{3} / \mathrm{km} /$ day of Sargassum 9 months out of the year, the total potential for emissions reductions across the Caribbean is $\sim 8 \times 10^{5}$ to $\sim 2 \times 10^{6} \mathrm{tCO}_{2} \mathrm{e} /$ year at a cost of $\$ 39.91$ to $\$ 95.98 / \mathrm{tCO}_{2} \mathrm{e}$. If carbon credits could be issued for these emissions reductions and sold for even the low price of just $\$ 35 / \mathrm{tCO}_{2} \mathrm{e}$ (e.g., to the European Union Emissions Trading System, EU ETS, or Carbon Offsetting and Reduction Scheme for International Aviation, CORSIA) then $42-93 \%$ of LCM + Towline + SOS Carbon Barge system costs could be offset. Future net profits from rising carbon prices can be reinvested into expanding Sargassum cleanup activity and developing other valorization methods that provide jobs and value-added products to locals. Note that $\$ 100 / \mathrm{tCO}_{2} \mathrm{e}$ is equivalent to $\$ 0.012 / \mathrm{km}$ for a car that uses $5 \mathrm{~L} / 100 \mathrm{~km}$ gasoline $(\sim 47 \mathrm{mpg})$.

Each LCM net, with $d=1 \mathrm{~m}, l=3 \mathrm{~m}$, and $M_{\text {net }}=2$, holds $\sim 0.2$ wet tonnes of Sargassum, which is equivalent to $\sim 0.03$ to $0.08 \mathrm{tCO}_{2} \mathrm{e}$ if sequestered. As a quick metric, this represents $\sim 1.0$ to $2.5 \mathrm{tCO}_{2} \mathrm{e}$ sequestered per hour for a single $\mathrm{LCM}$ operating at maximum efficiency, compared to $<0.05 \mathrm{tCO}_{2} \mathrm{e}$ per hour in emissions generated by an LCM boat's outboard engine.

\section{Discussion}

\subsection{SOS Carbon Credits}

It is important to note that emissions reductions cannot qualify for saleable carbon offsets unless the "additionality" requirement is satisfied. In other words, if a negative emissions initiative would have been pursued with or without revenue from selling carbon credits, then it is not additional. For example, LCM cleanup along resort coastlines may not be completely additional by itself because, notwithstanding increased collection volumes and decreased process emissions from replacing current methods with LCMs, such collection is effectively paid for by increased hotel occupancy. On the other hand, 
LCM cleanup along civilian beaches is likely dependent on issuance of carbon credits. Nevertheless, emissions reductions from the SOS Carbon deep sea disposal strategy would be additional for Sargassum collected from both resort and civilian beaches, however offset value would be relative to emissions from landfill and coastal decomposition, respectively. Emissions from landfill and coastal methanogenesis must be better quantified through field measurements if carbon credits are to be pursued.

In Fall 2018, the IPCC "Special Report" concluded that limiting global warming to $1.5^{\circ} \mathrm{C}$ will require carbon dioxide removal (CDR; or "negative emissions technology" NETs). A portfolio approach is recommended-technical risk being spread over many different types of CDR/NETs technologies. Simple and creative approaches such as SOS Carbon, thus, appear as common-sense initiatives compared to more risky and expensive technologies. Figure 8 shows a visual comparison between the SOS Carbon strategy and other potential NETs [41].

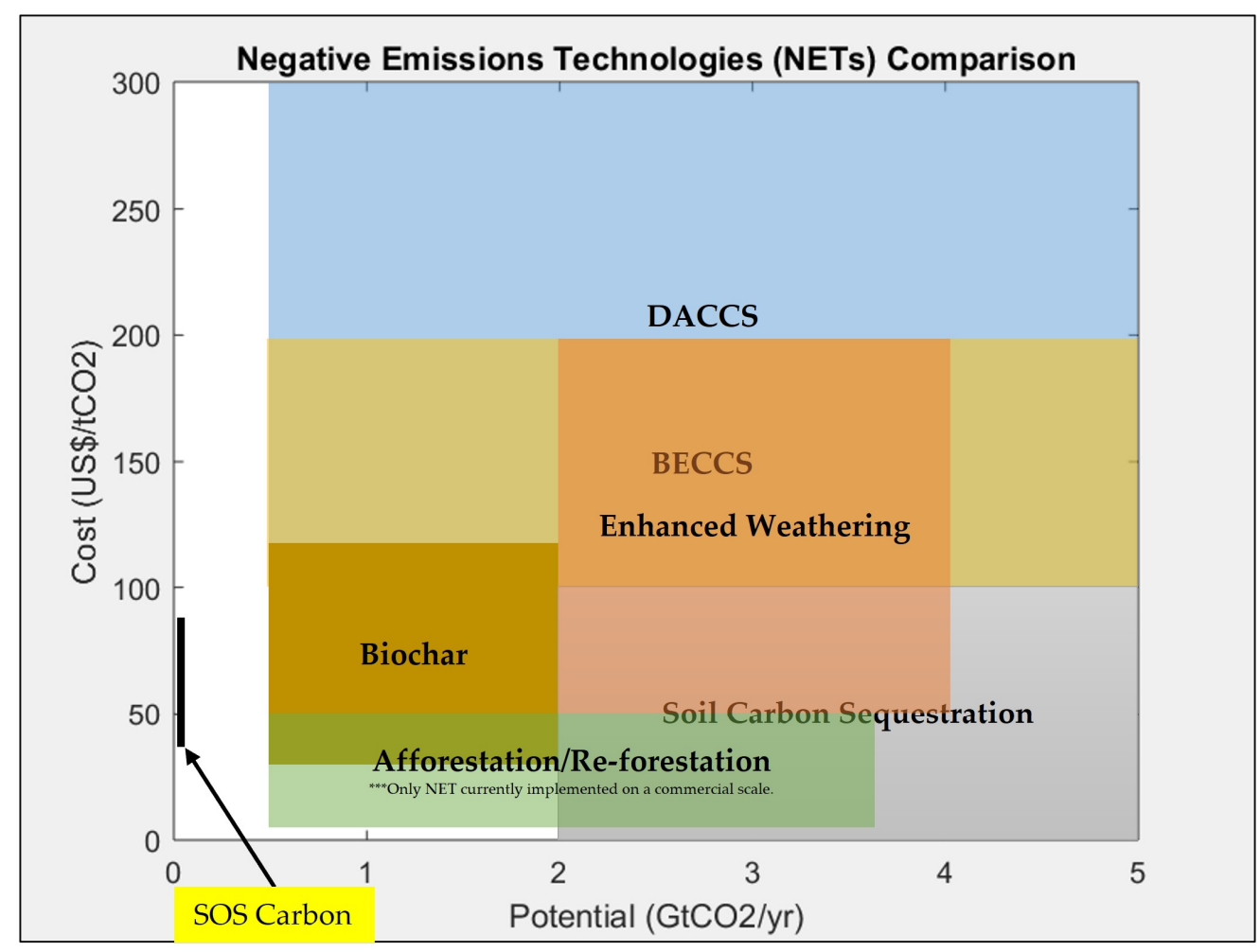

Figure 8. A comparison between SOS Carbon and other (global scale) negative emissions technologies (NETs): Direct Air Carbon Capture and Storage (DACCS), Bioenergy with Carbon Capture and Storage (BECCS), enhanced weathering, biochar, soil carbon sequestration, and afforestation/reforestation [41]. SOS Carbon is considerably cheaper and boasts a large potential for a project with a relatively small geographic footprint and capital cost/lead time.

Collateral damage to coastal carbon sinks must be studied in greater detail before they can be counted as part of the SOS Carbon strategy emissions reduction potential. Whether or not towline disposal can also generate emissions reductions worthy of carbon credits is worth future consideration if the fate of released Sargassum can be predicted and/or monitored. 
Initially, SOS Carbon credits would likely be most successful in 3rd party registries as voluntary credits for airlines and travel companies serving the Caribbean because they offer brand value and because SOS Carbon credits could be offered to tourists as a means of combating flight shame ("flygskam").

\subsection{Offshore SOS Carbon Fleet}

The SOS Carbon pilot system served as a validation of the SOS Carbon barge, but was itself an ocean-going vessel capable of intercepting mats of Sargassum over deep water and in situ sequestering. If SOS Carbon credits are realized, intercepting mats over deep water may become a widespread mode of carbon offsetting activity.

A "fleet planning tool" would be required to utilize present and/or historical satellite imagery and environmental data (current and wind data, e.g., Hybrid Coordinate Ocean Model, HYCOM, and National Centers for Environmental Prediction, NCEP) in an area of interest, identify Sargassum mats, especially large eccentric mats or long windrows with high density, quantify the probability that each mat is likely to hit critical coastline (this is necessary for demonstrating additionality), and then optimize a path for SOS Carbon vessels to sink the mats.

There have been many efforts to improve satellite observation and oceanographic understanding of Sargassum for making more accurate landfall forecasts, notably the Sargassum Watch System (SaWS) [4,42,43]. Sargassum Detection and Monitoring Tool (SAMtool) [44] represents perhaps the most advanced of these forecasting tools, with $20 \mathrm{~m}$ resolution, 2-3 day frequency, and advanced drift modeling. Figure 9 shows a simple particle tracking model where open-water SOS Carbon vessels might operate in the Mona Passage and Muertos Trough. All the Lesser Antilles, Jamaica, Cuba, Cayman Islands, Belize, Turks and Caicos, The Bahamas, Mexico, Costa Rica, and Panama all have very deep waters just off their shores.

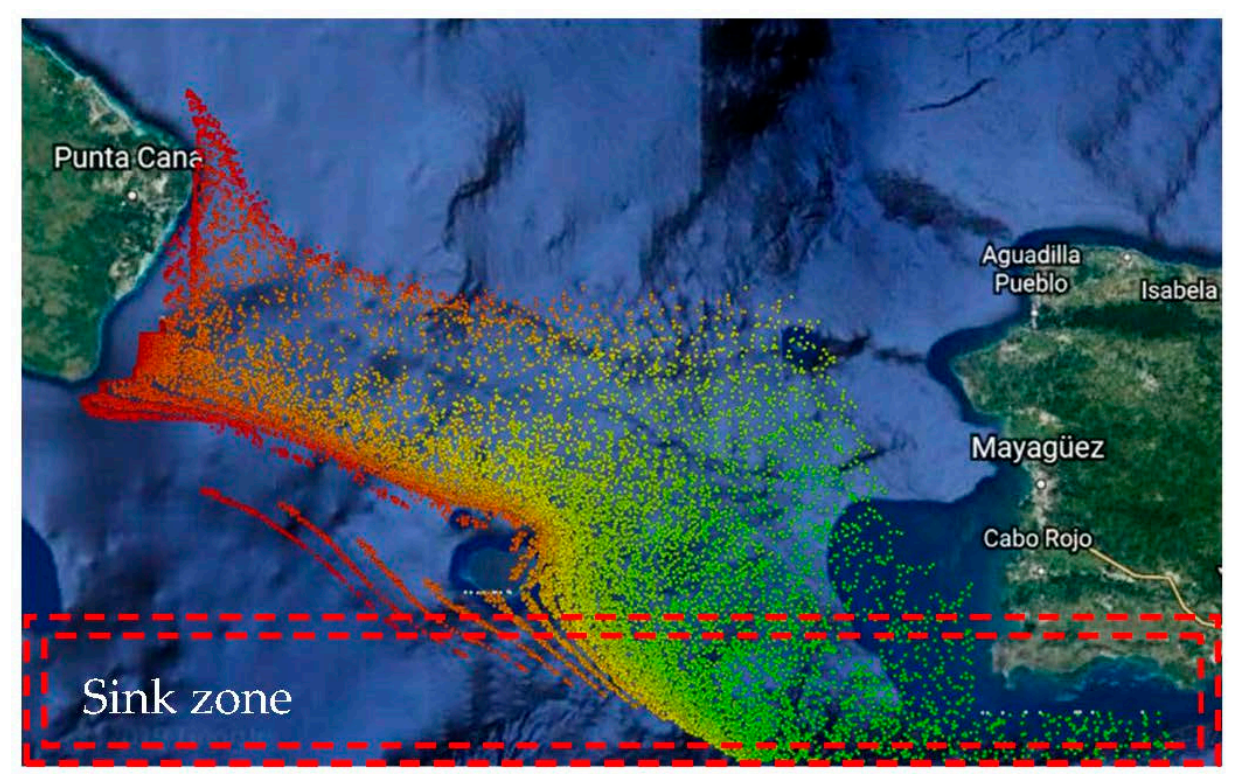

Figure 9. The output of a proof-of-concept forward-tracking model [45], which uses Hybrid Coordinate Ocean Model (HYCOM) surface velocity data (this example between 18 February 2019 and 25 February 2019) to trace virtual particles to Punta Cana from its entrance to the Mona Passage. The sink zone has >1000 m depth where SOS Carbon vessels may perform sinking activity. 
While SOS Carbon vessels should only target Sargassum destined to make landfall, these vessels are not a means for achieving a 100\% clean beach. Barriers and LCMs are the only way to attain $\sim 100 \%$ clean beaches. The primary purpose of SOS Carbon vessels would be carbon offsetting. Reducing the overall amount of Sargassum landfall could be a secondary benefit.

\subsection{Environmental Impact}

While the negative ecological and environmental impacts of Sargassum landings in the Caribbean are evident, Sargassum is important to the ecology of the North Atlantic. There, it is a habitat for 10 endemic species and a nursery and breeding ground for several endangered or threatened species of turtle and eel, and host to many long-distance travelers such as bluefin tuna, whale sharks, and manta rays. While Sargassum was not present in the central Atlantic until relatively recently, SOS Carbon should refrain from targeting open ocean Sargassum that is functioning as an ecological resource.

SOS Carbon's potential impact on deep sea ecology must be considered and studied on a small scale before widespread implementation can take place. Surface productivity in the form of microalgae, macroalgae, wood, carcasses, and other organic matter is the primary energy input and driver of deep-sea ecological processes. Sargassum has been photographed at depths as great as $5000 \mathrm{~m} \mathrm{[46]} \mathrm{and} \mathrm{could} \mathrm{theoretically} \mathrm{be} \mathrm{present} \mathrm{at}$ greater depths. Camera and bait experiments have identified several invertebrates that are attracted to and consume Sargassum $[47,48]$. While the importance of organic enrichment, specifically in deep-sea canyons, by sinking biomass has been recognized and quantified in specific cases, little is known about the ecological effect of this phenomena [49]. What is certain is that the deep ocean receives large amounts of organic enrichment from many sources, including Sargassum that sinks due to natural senescence and/or wind-induced sinking. What is unknown is how SOS Carbon would contribute to the organic enrichment that is already happening in the areas of interest.

The LCM + Towline + SOS Carbon Barge system only collects and sequesters Sargassum that has already hit barriers or is about to land on beaches. SOS Carbon barges should at first be discharged in a consistent, concentrated area such that Sargassum fate and effect on the deep ocean bottom can be continuously monitored. Similar to the scientific effort monitoring deep sea mining exploration in the Clarion-Clipperton Zone, SOS Carbon would create the opportunity to help understand some of the deepest ecosystems in the Atlantic. Ideally, private interests will be motivated to document and widely disseminate information as the system and best practices are developed.

The process risks of (1) bycatch and (2) migration of sunken Sargassum outside the intended sink zone as it precipitates from the critical depth to the ocean bottom, must be monitored and controlled. While close visual monitoring of LCM collection can effectively prevent bycatch, it is important to note that most large organisms usually abandon Sargassum mats when they come close to making landfall and remaining life unfortunately dies anyway due to eutrophication. The extent of open-ocean SOS Carbon bycatch must be studied and countermeasures developed, if necessary. Sink zones should be chosen such that there is no sensitive area nearby that could be affected by moderate migration of Sargassum and 3D benthic current modeling (e.g., plume modeling techniques) should be applied to the selection of sink zones to reduce the risk of coastal upwelling of sunken Sargassum.

\section{Conclusions}

It has been a decade since the beginning of the Sargassum inundations in the Caribbean. To date, organized solution efforts have been limited to tourist locations. If Sargassum is the "new norm" then a solution must be developed for the entire Caribbean. The LCM + Towline (+) SOS Carbon Barge systems provide cost-effective, scalable, and sustainable options which also have the potential to eliminate far more emissions than are produced. Specific results of this study can be summarized as follows: 
- LCMs can increase Sargassum collection by lowering costs and extending technology accessibility beyond tourist locations;

- $\quad \mathrm{LCM}+$ Towline + SOS Carbon Barge system provides a sustainable, high-capacity, inconspicuous means of Sargassum disposal for the increasing volumes of collected Sargassum that cannot be $100 \%$ valorized;

- $\quad$ LCM + Towline + SOS Carbon Barge system has the potential to offset up to $1.356 \rightarrow 3.029 \mathrm{tCO}_{2} \mathrm{e} / \mathrm{dmt}$ Sargassum (less process emissions), but additionality must be considered further;

- $\quad$ LCM + Towline system provides a low-cost alternative to the SOS Carbon barge, but non-permanence of emissions reductions must be considered further and local oceanographic context must be carefully considered and processes conducted responsibly so as to not cause increased landfall in neighboring beaches;

- SOS Carbon pilot test provided full-scale pump-to-depth hardware validation and the SOS Carbon system could one day be deployed on a fleet of ocean-going vessels.

The downward spiral of global climate issues and COVID-19 travel suppression of Caribbean tourism is sadly a perfect example of "interlocking crises." COVID-19 has further diverted attention away from the issue of Sargassum. If Caribbean tourism and coastal economies are to enjoy a strong post-pandemic recovery, the issues of Sargassum and flight shame must be addressed.

Since COVID-19 struck, there has been a push to "build back better." By addressing the Sargassum problem, the Caribbean can become a leader in sustainable development and infrastructure can be established for more such programs across Latin America using problems as opportunities for negative emissions solutions. Just as reducing trade barriers relieves pressure on developing nations to overexploit natural resources, wide acceptance and fair pricing of SOS Carbon credits can accelerate the spread of this more sustainable Sargassum management solution (EU ETS and CORSIA are encouraging examples [50,51]). Caribbean leaders have championed the idea of debt swapping for investments in climate adaption and resilience [52,53]. Instead of artificial debt forgiveness, SOS Carbon additionally offers creditors in developed regions reliable, low-cost carbon credits.

The Caribbean sub-region, especially the Caribbean SIDS, is highly vulnerable to increasingly costly natural disasters and suffers from high debt-to-GDP. As a result, environmental resources are overexploited for primary product exports and there are no resources to minimize damaging side-effects. Growing populations rely on increasingly threatened coastal resources. Solving the problems of Sargassum and flight shame is perhaps the easiest way to make space for sustainable economic growth in the Caribbean by creating a negative emissions industry and renewing investment confidence in Caribbean tourism. International advocacy and financing, Caribbean-wide adoption and development, and local manufacturing and operation can enable the creation of a sustainable Sargassum-based negative emissions ecosystem that captures the Brundtland Report's spirit of multilateralism and public inclusivity in pursuit of a viable solution to a regional crisis [54].

\section{Patents}

SOS Carbon is covered under patent application PCT/US2019/068295 and the LCM is covered under patent application PCT/US/2021/017873.

Supplementary Materials: The following is available online at https:/ /www.mdpi.com/article/ 10.3390/phycology1010004/s1 for evaluating the equations derived in Section 2 "Materials and Methods": "Economics and Carbon Accounting Model.xlsx".

Author Contributions: Conceptualization, L.A.G. and A.H.S.; Data curation, L.A.G.; Formal analysis, L.A.G.; Funding acquisition, A.G.B.L.; Investigation, L.A.G., A.G.B.L., F.E.R., S.S.V. and A.H.S.; Methodology, L.A.G.; Project administration, A.G.B.L.; Resources, A.G.B.L.; Software, L.A.G.; Supervision, A.H.S.; Validation, L.A.G.; Visualization, L.A.G.; Writing—original draft, L.A.G.; Writingreview \& editing, L.A.G. and A.H.S. This project was Luke A. Gray's Master's thesis at MIT. Alexander 
H. Slocum was the PI on the project. All authors have read and agreed to the published version of the manuscript.

Funding: There is no grant funding associated with this submission. Financial sponsors are listed in "Acknowledgements" below.

Institutional Review Board Statement: Not applicable.

Informed Consent Statement: Not applicable.

Data Availability Statement: The results of this study can be reproduced using the data and equations presented in Section 2 "Materials and Methods" and a model for evaluating said equations is available in Supplementary Material ("Economics and Carbon Accounting Model.xlsx"). More details on critical depth experiments as well as the design and construction of the SOS Carbon and LCM systems can be found in [25] or made available by reasonable request from the corresponding author.

Acknowledgments: This work was supported by the following financial sponsors: Banco Popular Dominicano, Ministerio de Turismo Republica Dominicana (MITUR), SOS Carbon S.R.L., Massachusetts Institute of Technology (MIT) Department of Mechanical Engineering, Pontificia Universidad Católica Madre y Maestra (PUCMM), Consorcio Energético Punta Cana-Macao S.A. (CEPM), Hard Rock Hotel \& Casino Punta Cana, Majestic Resorts Punta Cana, Meliá Hotels International S.A., Grumasa Dominicana, Codelpa, Grupo Ramos, Seguros Universal, Green Garden, and Volo Foundation. This work was also supported by the following goodwill sponsors: Armada de la República Dominicana (provided GC-111 vessel/crew for $\sim 3$ mo during pilot), IMCA Implementos y Maquinarias (provided excavator and telehandler for pilot assembly), Xylem Dewatering Solutions Inc. (provided the Godwin DPC300 pump for pilot), Fundación Cap Cana (provided accommodations and access to marina), and Autoridad Nacional de Asuntos Marítimos (ANAMAR; supported import and temporary admission of pilot hardware). Many thanks are given to Bob Gray, Isabel Leon, Pedro Peralta, and Carlos Perdomo for their help and support throughout the project. The authors would also like to thank members of the MIT Precision Engineering Research Group for their support of Luke Gray's research as a graduate student studying Sargassum collection and sequestration. Additionally, the authors would like to thank Daniel G. Nocera, from the Department of Chemistry at Harvard University, for his guidance while performing elemental analysis on Sargassum. The authors also owe special thanks to the Dominican Republic Navy's GC-111 Centaurus crew for help constructing and conducting pilot tests: T/N Marbel Rosario Ramirez Ortiz (Comandante), T/N Yuberto Heredia Garcia (Jefe de Máquinas), T/F Feliciano Mezquita Roso (2 do Comandante), T/C Carlos A. Rodriguez Perez (Para Servicio), T/C Santo J. Guerrero Mojica (Para Servicio), Sgto. Wilson de la Rosa Garcia (Contra maestre), Sgto. José Cruz Lopez (1 er. Asistente), Sgto. Anderson Ramirez Mercedes (Motorista), Sgto. Marcelo Lopez Céspedes (Motorista), Cabo Lenny Sanchez Liriano (Para Servicio), Wagner Rodriguez Beltre (Para Servicio), José Eduardo Valdez (Para Servicio), and Juan B. Perez Amador (Para Servicio).

Conflicts of Interest: Luke A. Gray and Andres G. Bisono Leon are employed by and have ownership interest in SOS Carbon S.R.L. and Aliquam L.L.C., the latter owning rights to patent application “SEQUESTERING BIOMASS IN WATER" PCT/US2019/068295 and patent application "MODULAR SYSTEMS FOR RETROFITTING SMALL WATERCRAFT AS COLLECTION BOATS FOR SARGASSUM SEAWEED" PCT/US2021/017873, which cover the SOS Carbon and LCM systems, respectively. Luke A. Gray and Prof. Alexander H. Slocum are named inventors of said patent applications. The funders had no role in the design of the study; in the collection, analyses, or interpretation of data; in the writing of the manuscript, or in the decision to publish the results. "SOSCarbon.com" is a website dedicated to providing information about the strategy and the best appropriate path forward as an open design, non-profit, or other business model is expected to evolve as the systems are built, deployed, and used; however in the meantime for purposes of pursuing the patents needed to help ensure quality implementation of the LCM and prevent cheap dangerous knockoffs from being sold, an LLC has been formed. 


\section{Appendix A}

Elemental analysis was quantified through inductively coupled plasma mass spectroscopy (ICP-MS) on an Agilent 7900 and analyzed using the ICP-MS MassHunter software. Fresh Sargassum was oven-dried at $150{ }^{\circ} \mathrm{C}$ before being dissolved in trace metal grade nitric acid (VWR) at concentration of $10 \mathrm{mg}$ dried Sargassum per mL HNO3 for five days. Samples were then diluted into a $2 \% \mathrm{HNO} 3$ solution and analyzed with an $89 \mathrm{Y}$ internal standard against an 8-point standard curve over the range of $0.1 \mathrm{ppb}$ to $300 \mathrm{ppb}$. The correlation was $>0.999$ for all analyses of interest. Data was collected on Spectrum Mode with six replicates per sample and 100 sweeps per replicate.

\section{Appendix B}

The LCM is a safety-critical device. Its design may look simple and tempting to imitate. However, designing the LCM to absorb large operational forces, regardless of the condition of the host boat, is not straightforward. Production designs for the LCM are supported by a closed-loop spreadsheet that calculates internal and contact stresses throughout the entire structural loop. Deterministic shape selection, member sizing, material selection, rigging accessories, weld quality, and proper assembly, maintenance instructions, and training are critical to safe operation of the LCM. Figure A1 shows a free-body diagram of the LCM.

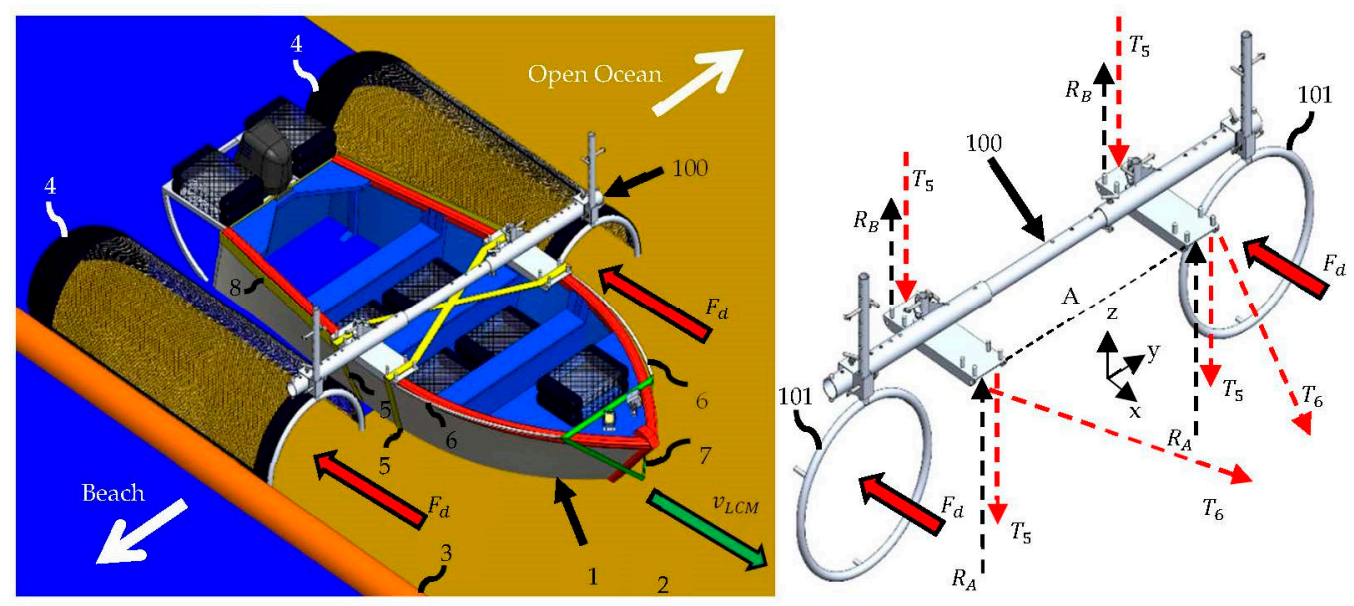

Figure A1. (Left) ISO view of the LCM 100, mounted on boat 1, moving through Sargassum 2, accumulated along barrier 3 , being collected into nets 4 . Tiedown straps 5 prevent the LCM from tipping forward due to the eccentricity of loads $F_{D}$ acting at the waterline. Lift-rated chains 6 are attached with shackles to LCM 100 and to a round, endless sling 7 that fits over the bow of boat 1 to resist drag forces $F_{D}$. (Right) Free-body diagram showing drag forces $F_{D}$ acting on net holders 101 . These forces are ultimately arrested by chain tension $T_{6}$. The tipping moment due to eccentricity of drag forces $F_{D}$ about fulcrum axis $\mathrm{A}$ is arrested by rear tiedown tension $T_{5}$. Note that the reaction forces $R_{A}$ and $R_{B}$, where $R_{B}<R_{A}$ in operation, represent extremes in a pressure distribution from A to $B$, which depends on the flatness/contour of the gunwale. $R_{B}>0$ assuming preload $T_{5}$ is not overcome.

Drag force $F_{D}$ on a filled net of Sargassum with $(d, l)=(1 \mathrm{~m}, 3 \mathrm{~m})$ towed at the max operating speed of $v_{L C M}=3 \mathrm{~m} / \mathrm{s}$ can be as high as:

$$
F_{D}=\frac{1}{2} \times \rho_{s w} \times C_{D} \times \pi \times \frac{d^{2}}{4} \times v_{L C M}^{2}>7000 \quad[\mathrm{~N}]
$$


where $C_{D}=2$ is the max drag coefficient on a full net of Sargassum assuming complete loss of momentum of displaced seawater. Even assuming no extreme chain angles, chain tensions could be $>2000 \mathrm{lbs}$. Channel skis help increase the moment arm between the channel ski fulcrum and rear tiedown tension. Still, with freeboard $f=0.75 \mathrm{~m}$, the tipping moment acting on the LCM could be as high as:

$$
M_{\text {tip }}=F_{D} \times f>5000 \quad[\mathrm{~N}-\mathrm{m}]
$$

With channel ski length $l_{\text {channel }}=0.75 \mathrm{~m}$, the rear tiedown tension resisting the tipping moment could be as high as:

$$
T_{5}=\frac{M_{\text {tip }}}{l_{\text {channel }}}>7000 \quad[\mathrm{~N}]
$$

Rated and certified pins, tie-downs, chains, shackles, links, slings, aluminum, and filler material is required. UV, saltwater, and mechanical wear can have a significant effect on the integrity of these components and must be inspected prior to every day of operation.

Net holders are designed with the lowest factor of safety such that at excessive operating speeds or in the case of a collision (e.g., with shallow rocks), net holders will fail predictably, protecting personnel and the rest of the LCM. For repairs to happen, all incidents must be reported, which enables causes to be identified and prevented in the future.

The round endless sling that fits over the bow of the boat, and the lift-rated shackles and chains that connect channel skis to the sling, rely on the bulk strength of the keel and gunwales to secure the LCM during regular operation and prevent it from striking operators during a collision. Other attachment mechanisms can place too much stress on specific and potentially damaged components of the boat being used, and are therefore not safe.

We strongly disapprove of any attempts to simply imitate the LCM device because if substandard parts are used, serious harm to people and/or equipment could occur.

\section{Appendix C}

The SOS Carbon pilot system (Figures 6 and 7) feeds Sargassum to the suction inlet device by moving through mats of Sargassum (the addition of a J-boom + boomvane can increase collection width). This "mowing method" is best suited for sinking long Sargassum windrows. However, large eccentric Sargassum mats may be best fed to suction inlet devices via an encirclement method, wherein a long containment boom encircles a mat of Sargassum and pulls it towards the SOS Carbon vessel, similar to the fishing method of purse seining. This method is illustrated in Figure A2. 

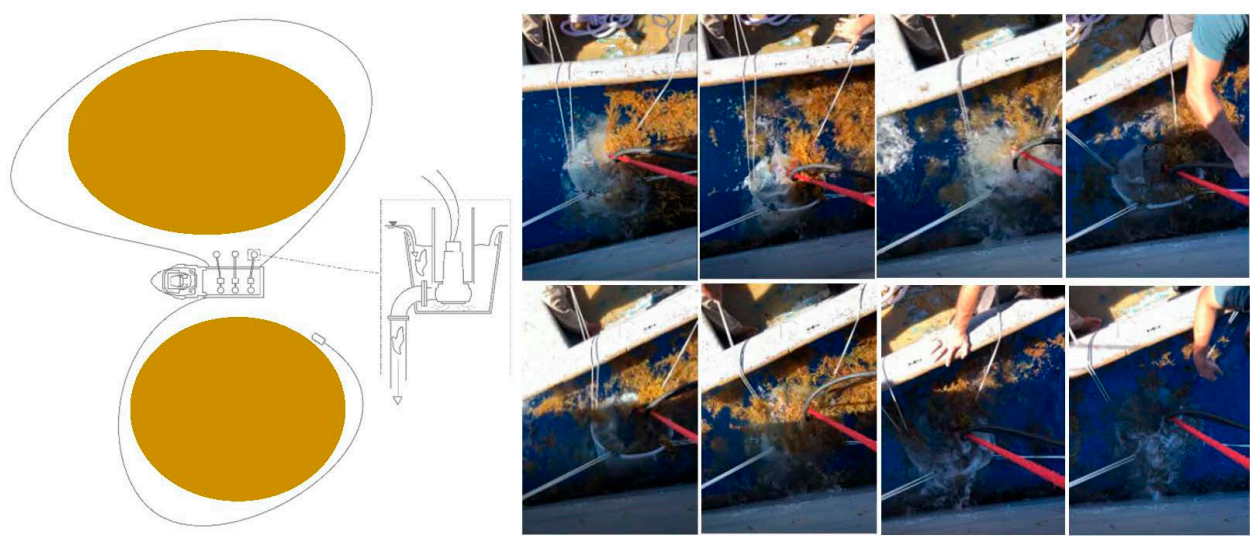

Figure A2. (Left) A method of encircling Sargassum using long containment booms and pulling Sargassum towards suction inlet devices. This method may employ its own special suction inlet device. (Right) Tests of a suction inlet device vaguely resembling a floating weir oil skimmer with a submersible pump therein. A rectangular sump, with a straight weir, could sustain higher pump flow rates at scale and a single damped degree-of-freedom linkage could conveniently deploy and provide wave-following ability to maintain high solids concentration.

\section{References}

1. Franks, S.J.; Johnson, R.D.; Ko, S.D.; Sanchez-Rubio, G.; Hendon, R.J.; Lay, M. Unprecedented influx of pelagic Sargassum along Caribbean island coastlines during summer 2011. Proc. Gulf Caribb. Fish. Inst. 2011, 64, 6.

2. Gower, J.; Young, E.; King, S. Satellite images suggest a new Sargassum source region in 2011. Remote Sens. Lett. 2013, 4, 764-773. [CrossRef]

3. Johnson, D.R.; Ko, D.S.; Franks, J.S.; Moreno, P.; Sanchez-Rubio, G. The Sargassum invasion of the Eastern Caribbean and Dynamics of the Equatorial North Atlantic. Proc. Gulf Caribb. Fish. Inst. 2012, 65, 102.

4. Wang, M.; Hu, C. Mapping and quantifying Sargassum distribution and coverage in the Central West Atlantic using MODIS observations. Remote Sens. Environ. 2016, 183, 350-367. [CrossRef]

5. Putman, N.F.; Goni, G.J.; Gramer, L.J.; Hu, C.; Johns, E.M.; Trinanes, J.; Wang, M. Simulating transport pathways of pelagic Sargassum from the Equatorial Atlantic into the Caribbean Sea. Prog. Oceanogr. 2018, 165, 205-214. [CrossRef]

6. de Széchy, M.T.M.; Guedes, P.M.; Baeta-Neves, M.H.; Oliveira, E.N. Verification of Sargassum natans (Linnaeus) Gaillon (Heterokontophyta: Phaeophyceae) from the Sargasso Sea off the coast of Brazil, western Atlantic Ocean. Check List 2012, 8, 638-641. [CrossRef]

7. Wang, M.; Hu, C.; Barnes, B.B.; Mitchum, G.; Lapointe, B.; Montoya, J.P. The great Atlantic Sargassum belt. Science 2019, 365, 83-87. [CrossRef] [PubMed]

8. Oviatt, C.A.; Huizenga, K.; Rogers, C.S.; Miller, W.J. What nutrient sources support anomalous growth and the recent Sargassum mass stranding on Caribbean beaches? A Rev. Mar. Pollut. Bull. 2019, 145, 517-525. [CrossRef] [PubMed]

9. Innovative system to control the arrival of Sargassum to the coasts of Quintana Roo. The Yucatan Times, 12 October 2018.

10. Milledge, J.J.; Maneein, S.; Lopez, E.A.; Bartlett, D. Sargassum inundations in Turks and Caicos: Methane potential and proximate, ultimate, lipid, amino acid, metal and metalloid analyses. Energies 2020, 13, 1523. [CrossRef]

11. World Travel \& Tourism Council. Caribbean Resilience and Recovery: Minimising the Impact of the 2017 Hurricane Season on the Caribbean's Tourism Sector; World Travel \& Tourism Council: London, UK, 2017.

12. World Travel \& Tourism Council. Economic Impact Reports; World Travel \& Tourism Council: London, UK, 2020.

13. Resiere, D.; Valentino, R.; Neviere, R.; Banydeen, R.; Gueye, P.; Florentin, J. Sargassum seaweed on Caribbean islands: An international public health concern. Lancet 2018, 392, 2691. [CrossRef]

14. Zanolli, L. Why Seaweed Is Strangling Mexican Tourism, and How Science Could Help; MIT Technology Review: Cambridge, MA, USA, 2019.

15. Tourism down 30-35\% due to Sargassum: Playa del Carmen mayor-elect. Mexico Daily News, 4 August 2018.

16. Government predicts 30\% drop in tourism due to Sargassum invasion. Mexico Daily News, 9 May 2019.

17. Jessop, D. Sargassum a Continuing Challenge for Tourism; The Caribbean Council: London, UK, 2019.

18. Sargassum a potential natural disaster for Caribbean beaches: Researchers. Mexico Daily News, 3 August 2018.

19. CARICOM. Millions of Dollars, Massive Manpower Needed to Tackled Sargassum Seaweed; CARICOM: Georgetown, Guyana, 2015.

20. Milledge, J.J.; Harvey, P.J. Golden tides: Problem or golden opportunity? The valorisation of Sargassum from beach inundations. J. Mar. Sci. Eng. 2016, 4, 60. [CrossRef] 
21. Rodríguez-Martínez, R.E.; Roy, P.D.; Torrescano-Valle, N.; Cabanillas-Terán, N.; Carrillo-Domínguez, S.; Collado-Vides, L.; García-Sánchez, M.; van Tussenbroek, B.I. Element concentrations in pelagic Sargassum along the Mexican Caribbean coast in 2018-2019. PeerJ 2020, 8, e8667. [CrossRef]

22. Slocum, A.H. Symbiotic offshore energy harvesting and storage systems. Sustain. Energy Technol. Assess. 2015, 11, 135-141. [CrossRef]

23. Peng, V.; Slocum, A.H. Endemic water and storm trash to energy via In Situ processing. Renew. Sustain. Energy Rev. 2020, 134, 110272. [CrossRef]

24. Johnson, D.L.; Richardson, P.L. On the wind-induced sinking of Sargassum. J. Exp. Mar. Biol. Ecol. 1977, 28, 255-267. [CrossRef]

25. Gray, L.A. Sequestering Floating Biomass in the Deep Ocean: “Sargassum Ocean Sequestration of Carbon" (SOS Carbon). Master's Thesis, Massachusetts Institute of Technology, Cambridge, MA, USA, March 2020.

26. SOS Carbon, S.R.L. Available online: https://soscarbon.com/ (accessed on 8 August 2021).

27. “Fuel Energy Density." IOR Energy. Available online: https://web.archive.org/web/20100825042309/http://www.ior.com.au/ ecflist.html (accessed on 8 August 2020).

28. United States Naval Academy (USNA). EN400: Principles of Ship Performance, Chapter 7: Resistance and Powering of Ships; United States Naval Academy (USNA): Annapolis, MD, USA, 2020.

29. “Godwin DPC300." Xylem Inc. Available online: https://www.xylem.com/en-us/products-services/pumps-packaged-pumpsystems/pumps/self-priming-pumps/automatic-self-priming-pumps/dri-prime/cd-series/godwin-dpc300 (accessed on 8 August 2020).

30. Cengel, Y.A.; Cimbala, J.M. Fluid Mechanics: Fundamentals and Applications. McGraw-Hill Series in Mechanical Engineering, Chapter 11-5. 582; McGraw-Hill: New York, NY, USA, 2006.

31. Lomas, M.W.; Bates, N.R.; Buck, K.N.; Knap, A.H. Notes on "Microbial productivity of the Sargasso Sea and how it compares to elsewhere", and "The Role of the Sargasso Sea in carbon sequestration-Better than carbon neutral?". Sargasso Sea Alliance Sci. Rep. Ser. 2011, 6, 10.

32. Allan, W.S. Pelagic Sargassum: Evidence for major decrease in biomass. Deep. Sea Res. 1983, 30, 469-474.

33. Bauer, J.E.; Williams, P.M.; Druffel, E.R.M. 14C activity of dissolved organic carbon fractions in the north-central Pacific and Sargasso Sea. Nature 1992, 357, 667-670. [CrossRef]

34. Itoh, H.; Aoki, M.N.; Tsuchiya, Y.; Sato, T. Fate of organic matter in faecal pellets egested by epifaunal mesograzers in a Sargassum forest and implications for biogeochemical cycling. Mar. Ecol. Prog. Ser. 2007, 352, 101-112. [CrossRef]

35. Laffoley, D.; Baxter, J.M.; Thevenon, F.; Oliver, J. The Significance and Management of Natural Carbon Stores in the Open Ocean; Full Report; IUCN: Switzerland, Gland, 2014; p. 124.

36. Intergovernmental Panel on Climate Change (IPCC). National Guideline for National Greenhouse Gas Inventories: Volume 5-Solid Waste Disposal; Technical Report; Intergovernmental Panel on Climate Change (IPCC): Geneva, Switzerland, 2006.

37. Myhre, G.; Shindell, D.; Breon, F.-M.; Collins, W.; Fuglestvedt, J.; Huang, J.; Koch, D.; Lamarque, J.-F.; Lee, D.; Mendoza, B.; et al. 2013: Anthropogenic and natural radiative forcing. In Climate Change 2013: The Physical Science Basis. Contribution of Working Group I to the Fifth Assessment Report of the Intergovernmental Panel on Climate Change, Chapter 8; Stocker, T.F., Qin, D., Plattner, G.-K., Tignor, M., Allen, S.K., Boschung, J., Nauels, A., Xia, Y., Bex, V., Midgley, P.M., Eds.; Cambridge University Press: Cambridge, UK; New York, NY, USA, 2013.

38. U.S. Environmental Protection Agency (EPA). Greenhouse Gas Inventory Guidance: Direct Emissions from Stationary Combustion Sources; U.S. Environmental Protection Agency (EPA): Washington, DC, USA, 2016.

39. Register, F. Light-duty vehicle greenhouse gas emission standards and corporate average fuel economy standards; final rule. Fed. Regist. 2010, 75, 25330.

40. "PT Royal Lestari Utama." Tropical Landscapes Finance Facility (TLFF). Available online: http://tlffindonesia.org/project-ptroyal-lestari-utama/ (accessed on 8 August 2020).

41. Fuss, S.; Lamb, W.F.; Callaghan, M.W.; Hilaire, J.; Creutzig, F.; Amann, T.; Beringer, T.; de Oliveira Garcia, W.; Hartmann, J.; Khanna, T.; et al. Negative emissions-Part 2: Costs, potentials, and side effects. Environ. Res. Lett. 2018, 13, 063002. [CrossRef]

42. Hu, C.; Murch, B.; Barnes, B.B.; Wang, M.; Marechal, J.; Franks, J.; Johnson, D.; Lapointe, B.; Goodwin, D.S.; Schell, J.M.; et al. Sargassum watch warns of incoming seaweed. Eos 2016, 97, 10-15. [CrossRef]

43. Wang, M.; Hu, C. Predicting Sargassum blooms in the Caribbean Sea from MODIS observations. Geophys. Res. Lett. 2017, 44, 3265-3273. [CrossRef]

44. "SAMtool." CLS. Available online: https:// datastore.cls.fr/products/Sargassum/ (accessed on 8 August 2020).

45. Lett, C.; Verley, P.; Mullon, C.; Parada, C.; Brochier, T.; Penven, P.; Blanke, B. A Lagrangian tool for modelling ichthyoplankton dynamics. Environ. Model. Softw. 2008, 23, 1210-1214. [CrossRef]

46. Schoener, A.; Rowe, G.T. Pelagic Sargassum and its presence among the deep-sea benthos. Deep Sea Res. 1970, 17, 923-925. [CrossRef]

47. Fleury, A.; Drazen, J.C. Abyssal Scavenging Communities attracted to Sargassum and fish in the Sargasso Sea. Deep Sea Res. Part I Oceanogr. Res. Pap. 2013, 72, 141-147. [CrossRef]

48. Lawson, G.S.; Tyler, P.A.; Young, C.M. Attraction of deep-sea amphipods to macrophyte food falls. J. Exp. Mar. Biol. Ecol. 1993, 169, 33-39. [CrossRef] 
49. Harrold, C.; Light, K.; Lisin, S. Organic enrichment of submarine-canyon and continental-shelf benthic communities by macroalgal drift imported from nearshore kelp forests. Am. Soc. Limnol. Oceanogr. 1998, 43, 669-678. [CrossRef]

50. EU Emissions Trading System (EU ETS). European Union (EU). Available online: https://ec.europa.eu/clima/policies/ets_en (accessed on 8 August 2020).

51. Carbon Offsetting and Reduction Scheme for International Aviation (CORSIA). International Civil Aviation Organization (ICAO). Available online: https:/ / www.icao.int/environmental-protection/CORSIA/Pages/default.aspx (accessed on 8 August 2020).

52. Caribbean Leaders Discuss Debt for Climate Adaptation Swap, Caribbean Resilience Fund. IISD SDG Knowledge Hub. Available online: https:/ / sdg.iisd.org/news/caribbean-leaders-discuss-debt-for-climate-adaptation-swap-caribbean-resilience-fund/\#: $\sim\{\}:$ text=The $\% 20 \backslash \mathrm{T} 1 \backslash$ textquoterightDebt\%20for\%20Climate\%20Adaptation,region $\backslash \mathrm{T} 1 \backslash$ textquoterights $\% 20$ high $\% 20$ level $\% 20$ of $\% 20$ debt.\&text=According $\% 20$ to $\% 20$ ECLAC $\% 2$ C $\%$ the $\% 20$ Caribbean, climate $\% 2$ Drelated $\% 20$ disasters $\% 20$ since $\% 201990$ (accessed on 8 August 2020).

53. 3 Steps to Ensure the COVID-19 Economic Crisis Does Not Harm Climate Adaptation Plans. Global Center on Adaption, July 8, 2020. Available online: https:/ / gca.org/solutions/3-steps-to-ensure-the-covid-19-economic-crisis-does-not-harmclimate-adaptation-plans (accessed on 8 August 2020).

54. Report of the World Commission on Environment and Development: Our Common Future. World Commission on Environment and Development. Available online: https:/ / sustainabledevelopment.un.org/milestones/wced (accessed on 8 August 2020). 